\title{
REFERENCE CASES FOR USE IN THE CEMENTITIOUS BARRIERS PARTNERSHIP PROJECT
}

Cementitious Barriers Partnership

August 2010

CBP-TR-2010-006, Rev. 0 



\section{REFERENCE CASES FOR USE IN THE CEMENTITIOUS BARRIERS PARTNERSHIP PROJECT}

Cementitious Barriers Partnership

CBP-TR-2010-006, Rev. 0 


\section{ACKNOWLEDGEMENTS}

This report was prepared for the United States Department of Energy in part under Contract No. DEAC09-08SR22470 and is an account of work performed in part under that contract. Reference herein to any specific commercial product, process, or service by trademark, name, manufacturer, or otherwise does not necessarily constitute or imply endorsement, recommendation, or favoring of same by Savannah River Nuclear Solutions or by the United States Government or any agency thereof. The views and opinions of the authors expressed herein do not necessarily state or reflect those of the United States Government or any agency thereof. The authors would like to acknowledge the contributions of Elmer Wilhite of Savannah River National Laboratory, David Kosson of Vanderbilt University and CRESP, Jake Philip of the U.S. Nuclear Regulatory Commission, and Ed Garboczi of the National Institute of Standards and Technology for contributions to the document. They would also like to acknowledge the contributions of Media Services of Savannah River Nuclear Solutions and Savannah River National Laboratory personnel for editing and assistance with production of the document.

and

This report is based on work supported by the U. S. Department of Energy, under Cooperative Agreement Number DE-FC01-06EW07053 entitled 'The Consortium for Risk Evaluation with Stakeholder Participation III' awarded to Vanderbilt University. The opinions, findings, conclusions, or recommendations expressed herein are those of the author(s) and do not necessarily represent the views of the U.S. Department of Energy or Vanderbilt University.

\section{DISCLAIMER}

This work was prepared under an agreement with and funded by the U. S. Government. Neither the U.S. Government or its employees, nor any of its contractors, subcontractors or their employees, makes any express or implied: 1. warranty or assumes any legal liability for the accuracy, completeness, or for the use or results of such use of any information, product, or process disclosed; or 2. representation that such use or results of such use would not infringe privately owned rights; or 3. endorsement or recommendation of any specifically identified commercial product, process, or service. Any views and opinions of authors expressed in this work do not necessarily state or reflect those of the United States Government, or its contractors, or subcontractors, or subcontractors.

Printed in the United States of America

United States Department of Energy

Office of Environmental Management Washington, DC

This document is available on the U.S. DOE Information Bridge and on the CBP website: http://cementbarriers.org/

An electronic copy of this document is also available through links on the following websites: http://srnl.doe.gov/ and http://cementbarriers.org/ 


\section{FOREWORD}

The Cementitious Barriers Partnership (CBP) Project is a multi-disciplinary, multi-institutional collaboration supported by the United States Department of Energy (US DOE) Office of Waste Processing. The objective of the CBP project is to develop a set of tools to improve understanding and prediction of the long-term structural, hydraulic, and chemical performance of cementitious barriers used in nuclear applications.

A multi-disciplinary partnership of federal, academic, private sector, and international expertise has been formed to accomplish the project objective. In addition to the US DOE, the CBP partners are the Savannah River National Laboratory (SRNL), Vanderbilt University (VU) / Consortium for Risk Evaluation with Stakeholder Participation (CRESP), Energy Research Center of the Netherlands (ECN), and SIMCO Technologies, Inc. The Nuclear Regulatory Commission (NRC) is providing support under a Memorandum of Understanding. The National Institute of Standards and Technology (NIST) is providing research under an Interagency Agreement. Neither the NRC nor NIST are signatories to the CRADA.

The periods of cementitious performance being evaluated are up to or longer than 100 years for operating facilities and longer than 1000 years for waste management. The set of simulation tools and data developed under this project will be used to evaluate and predict the behavior of cementitious barriers used in near-surface engineered waste disposal systems, e.g., waste forms, containment structures, entombments, and environmental remediation, including decontamination and decommissioning analysis of structural concrete components of nuclear facilities (spent-fuel pools, dry spent-fuel storage units, and recycling facilities such as fuel fabrication, separations processes). Simulation parameters will be obtained from prior literature and will be experimentally measured under this project, as necessary, to demonstrate application of the simulation tools for three prototype applications (waste form in concrete vault, high-level waste tank grouting, and spent-fuel pool). Test methods and data needs to support use of the simulation tools for future applications will be defined.

The CBP project is a five-year effort focused on reducing the uncertainties of current methodologies for assessing cementitious barrier performance and increasing the consistency and transparency of the assessment process. The results of this project will enable improved risk-informed, performance-based decision-making and support several of the strategic initiatives in the DOE Office of Environmental Management Engineering \& Technology Roadmap. Those strategic initiatives include 1) enhanced tank closure processes; 2) enhanced stabilization technologies; 3 ) advanced predictive capabilities; 4) enhanced remediation methods; 5) adapted technologies for site-specific and complex-wide D\&D applications; 6) improved SNF storage, stabilization and disposal preparation; 7) enhanced storage, monitoring and stabilization systems; and 8) enhanced long-term performance evaluation and monitoring.

Christine A. Langton, PhD Savannah River National Laboratory

David S. Kosson, PhD Vanderbilt University / CRESP 
CONTENTS

ACKNOWLEDGEMENTS ...................................................................................................... ii

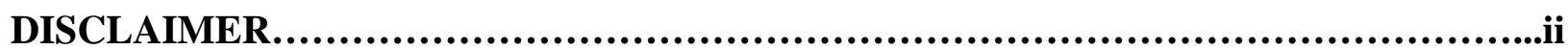

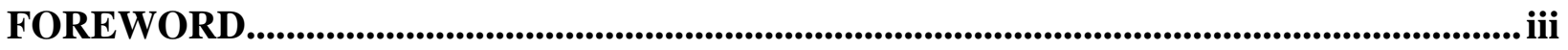

LIST OF FIGURES....................................................................vi

ABSTRACT......................................................................................1

1.0 INTRODUCTION

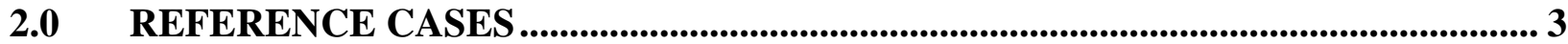

2.1 Reference Case Geometry ............................................................................ 3

2.3 Reference Case Time Periods ................................................................................ 5

2.4 Reference Case Outputs .......................................................................................5 5

2.5 Reference Case Cementitious Materials ............................................................... 6

2.6 Reference Disposal and Storage Units .....................................................................6 6

2.6.1 Cementitious Waste Form in Reinforced Concrete Vault................................... 7

2.6.2 Closed High-Level Waste Tank: ................................................................ 8

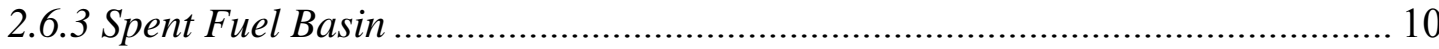

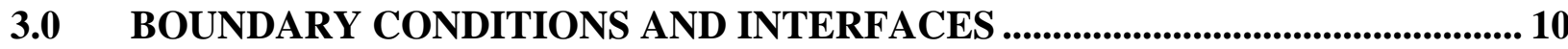

3.1 Cementitious Waste - Concrete.................................................................................. 11

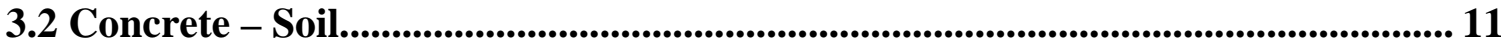

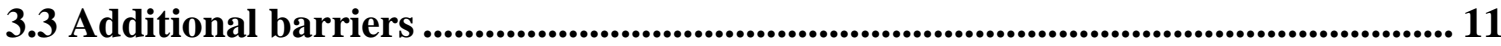

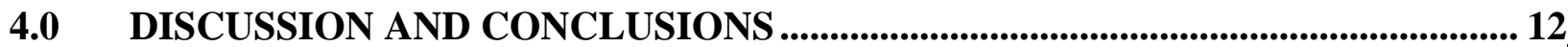

5.0 REFERENCES...............................................................13

6.0 ATTACHMENTS............................................................15

6.1 Attachment A - Reference Case Materials and Physical Properties...............16

6.2 Attachment B - Reference Case Fill Materials and Physical Properties..........................................................................21

6.3 Attachment C - Reference Case Salt Wasteform and Physical Properties.........................................................................26

6.4 Attachment D - Contaminant $K_{d}$ Data for Reference Case Ordinary (Oxidized Portland Cementitiuos Materials....................................31

6.5 Attachment $E$ - Contaminant $K_{d}$ Data for Reference Case Chemically Reduced Cementitious Materials..............................................36

6.6 Attachment F - Contaminant Solubility Data for Ordinary Portland (Oxidizing) Reference.............................................................39 


\section{CONTENTS Continued}

\subsection{Attachment G - Contaminant Solubility Data for Chemically}

Reducing Reference Case Cementitious Materials...................................43

6.8 Attachment H - Distribution Coefficients for Soil................................46 


\section{LIST OF FIGURES}

Figure 1. Examples of a One-Dimensional Reference Case Configuration for Evaluating Chemical and Physical Phenomena and Mechanisms..........4

Figure 2. Example of a Two-Dimensional Reference Case Configuration that Incorporates a Flow Field for PA Calculations................................4

Figure 3. Schematic Illustration of a Reinforced Concrete Vault Containing a Cementitious Low Activity Wasteform. Examples of Multi-layer Material and Interfaces Relevant to 1-D Mechanistic Studies are Illustrated.....................................................................

Figure 4. Schematic Illustration of a Closed High-level Waste Tank (Carbon Steel Tank in a Reinforced Concrete Vault) Containing a Cementitious Grout Fill. Examples of Multi-layer Material and Interfaces Relevant to 1-D Mechanistic Studies are Illustrated.......................................9

Figure 5. Schematic Diagram of Spent Fuel Pool During Operations. Examples of Multi-layer Material and Interfaces Relevant to 1-D Mechanistic Studies are Illustrated 


\title{
REFERENCE CASES FOR USE IN THE CEMENTITIOUS BARRIERS PARTNERSHIP PROJECT
}

\author{
Christine A Langton \\ Savannah River National Laboratory \\ Savannah River Nuclear Solutions \\ Aiken, SC 29808 \\ David S. Kosson and Andrew C. Garrabrants \\ Vanderbilt University, Department of Civil and Environmental Engineering \\ Consortium for Risk Evaluation with Stakeholder Participation III \\ Nashville, TN 37235
}

\begin{abstract}
The Cementitious Barriers Partnership Project (CBP) is a multi-disciplinary, multi-institution cross cutting collaborative effort supported by the US Department of Energy (DOE) to develop a reasonable and credible set of tools to improve understanding and prediction of the structural, hydraulic and chemical performance of cementitious barriers used in nuclear applications. The period of performance is $>100$ years for operating facilities and $>1000$ years for waste management. The CBP has defined a set of reference cases to provide the following functions: (i) a common set of system configurations to illustrate the methods and tools developed by the CBP, (ii) a common basis for evaluating methodology for uncertainty characterization, (iii) a common set of cases to develop a complete set of parameter and changes in parameters as a function of time and changing conditions, (iv) a basis for experiments and model validation, and (v) a basis for improving conceptual models and reducing model uncertainties. These reference cases include the following two reference disposal units and a reference storage unit: (i) a cementitious low activity waste form in a reinforced concrete disposal vault, (ii) a concrete vault containing a steel high-level waste tank filled with grout (closed high-level waste tank), and (iii) a spent nuclear fuel basin during operation. Each case provides a different set of desired performance characteristics and interfaces between materials and with the environment. Examples of concretes, grout fills and a cementitious waste form are identified for the relevant reference case configurations.
\end{abstract}

\subsection{INTRODUCTION}

The Cementitious Barriers Partnership (CBP) Project is a multidisciplinary effort supported by the US DOE to develop a set of tools to improve prediction of the structural, hydraulic and chemical performance of cementitious barriers used in nuclear applications over extended time frames (e.g., $>100$ years for operating facilities and > 1000 years for waste management) [1]. The CPB partners, in addition to the US DOE, are the U.S. Nuclear regulatory Agency (NRC), the National Institute of Standards and Technology (NIST), the Savannah River National Laboratory (SRNL), Vanderbilt University (VU) / Consortium for Risk Evaluation with 
Stakeholder Participation (CRESP), Energy Research Center of the Netherlands (ECN), and SIMCO, Technologies, Inc.

The project is focused on reducing uncertainties associated with current methodologies for assessing cementitious barrier performance and increasing the consistency and transparency of the assessment process. The results of this project will support long-term performance predictions and performance-based decision making and are applicable to several of the strategic initiatives in the U. S. Department of Energy (DOE) Environmental Management Engineering \& Technology Roadmap [2].

Performance assessments (PAs) for low-level waste facilities consist of 1) ground water flow and contaminant transport models, 2) air and radon transport pathway models, 3) inadvertent intruder analyses, and 4) all path ways human health risk analyses. The CBP project is focused on understanding and predicting the physical (hydraulic), chemical (contaminant retention and matrix evolution) and mechanical (structural) performance of cementitious barriers including waste zones for the subsurface flow and contaminant transport modeling. The set of simulation tools and data developed by this project will be applicable to near surface engineered waste disposal systems, e.g., waste forms, containment structures, entombments and environmental remediation, including decontamination and decommissioning (D\&D) activities. The simulation tools will also support analysis of chemical degradation of concrete used in nuclear facilities containment structures (spent fuel pools, dry spent fuel storage units, and recycling facilities, e.g., fuel fabrication, separations processes).

Three prototype reference systems/configurations described in this paper were defined to capture the essential features of the various types of engineered cementitious barriers. The reference cases are intended to provide:

- Full descriptions of the engineered structures that are sufficient to support Performance Assessment (PA) modeling;

- Simplified descriptions for 1- and 2-D analyses with representative materials and interfaces that will be used to evaluate time and spatially dependent evolution of performance in response to dynamic boundary conditions;

- Material descriptions and boundary conditions for experimental programs designed to support property-based chemical and physical constitutive models (non spatially dependent);

- Focused experimental programs that will be designed to reduce uncertainties associated with assumptions about material performance in interfacial regions between the waste, engineered materials, and environmental media. 


\subsection{REFERENCE CASES}

Key information required as inputs for defining systems and scenarios for PA modeling includes:

- Geometry

- Initial conditions

- Boundary conditions (e.g., fluxes, concentrations, etc.)

- Material properties that control matrix durability and contaminant leaching including:
a. Physical
b. Hydraulic
c. Structural
d. Chemical
e. Mineralogical

In addition, meaningful temporal and spatial scales must be selected to best address the modeling needs.

Key outputs required for cementitious barrier performance modeling include:

- Moisture and gas flow and constituent (contaminant) transport (leaching) function of time and spatial relationships,

- Changes in the physical / hydraulic properties of the barrier and waste as a function of time and spatial relationships.

\subsection{Reference Case Geometry}

Actual structures, engineered barriers, process equipment, and waste packages, etc. are three dimensional (3-D) and typically geometrically complex. For computational convenience, most low-level waste PAs reduce the 3-D complexities to 2-D cross sections that are considered to be reasonable approximations sufficient for addressing the geometrical issues. When cementitious barriers are present, 1-D approximations must be applied with caution and are rarely adequate due to the contrast in the hydraulic conductivities between the barrier and environmental media and/or waste zone.

The proposed CBP progression for the reference cases is illustrated in Figures 1 and 2. Mechanistic understanding will be obtained initially from 1-D phenomenological modeling and supporting experiments as shown in Figure 1. This information will be used as input to multidimensional PA flow and transport models, which are schematically illustrated in Figure 2, or in 1-D relative uncertainty analyses, such as those obtained with the Goldsim environmental transport modeling. The process for incorporating the phenomenological information into the 
multi-dimensional PA codes will be via algorithms developed from the 1-D experimental and associated modeling effort.

Boundary Condition A

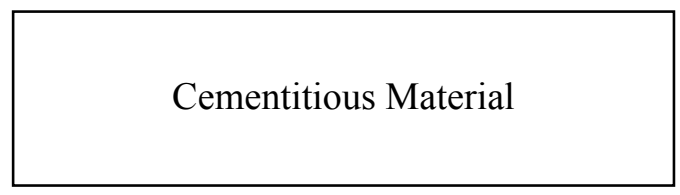

\begin{tabular}{|c|}
\hline Waste \\
\hline Cementitious Material \\
\hline Soil \\
\hline
\end{tabular}

Boundary Condition B

Figure 1. Examples of a One-Dimensional Reference Case Configuration for Evaluating Chemical and Physical Phenomena and Mechanisms.
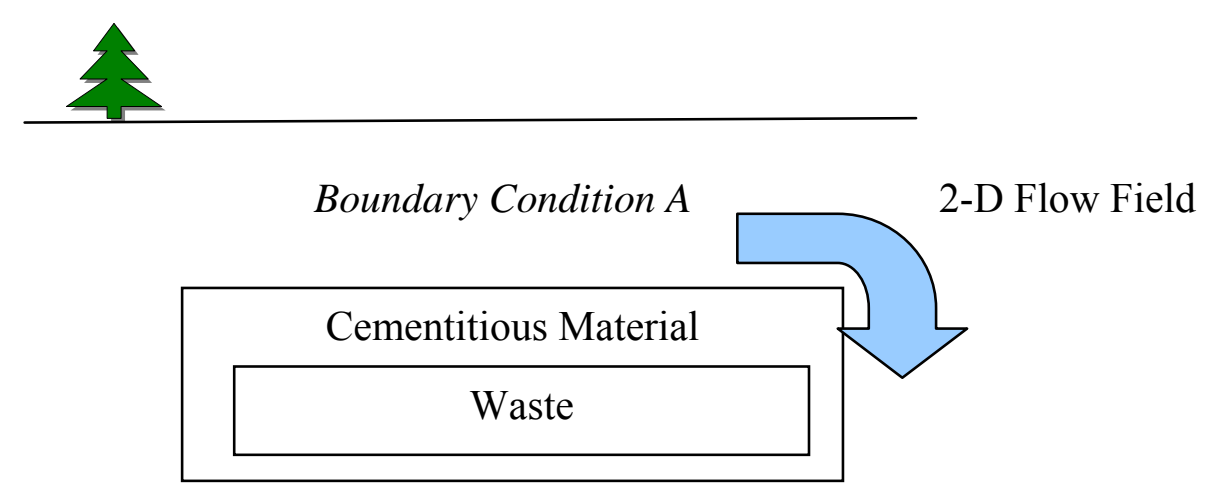

Boundary Condition B

Figure 2. Example of a Two-Dimensional Reference Case Configuration that Incorporates a Flow Field for PA Calculations.

\subsection{Reference Case Initial and Boundary Conditions}

Initial conditions typically defined in PAs that are important to the performance of disposal units, including engineered cementitious barriers are:

- Waste inventory and characteristics 
o Radioactive and chemical species of interest

- Influxes of water, gas, and chemical species at the system boundaries (fluxes across material interfaces)

o Water (\% saturation, $\mathrm{pH}, \mathrm{Eh}$, dissolved $\mathrm{O}_{2}$ and $\left.\mathrm{CO}_{2}\right)$

0 Air $\left(\% \mathrm{O}_{2}, \mathrm{CO}_{2}, \mathrm{H}_{2} \mathrm{O}\right.$ - relative humidity)

o Corrodent chemicals such as $\mathrm{Cl}^{-}, \mathrm{SO}_{4}{ }^{2-}$, alkalis, organic and inorganic acids

- Infiltration rates and flow along material interfaces (flow fields)

- Temperature and temperature cycling

- Structural condition

o Initial cracks from thermal stresses and drying shrinkage stresses

o Structure penetrations, construction joints, and other construction details

o Steel reinforcements (rebar and other)

- Episodic events such as seismic events and structural settlement or failure.

The CBP effort will focus primarily on the consequences of the influxes and fluxes across material interfaces and through materials of moisture, gas, and chemical species on the cementitious barrier materials as functions of long-term exposure. Temperature and temperature cycling will also be considered. The radioactive species of interest for the CBP reference cases are primarily $\mathrm{Cs}^{+}, \mathrm{Sr}^{2+}$, and the long lived mobile isotopes, Tc-99, I-129, C-14 and selected actinides, such as U and Pu or suitable surrogates. Degradation of structural penetrations, e.g., construction joints and other construction details will not be included in the mechanistic or phenomenological investigations except for the potential to provide fast pathways.

\subsection{Reference Case Time Periods}

Time periods over which performance predictions are required are 100 years for storage structures and 1000 to 10,000 years for disposal units. Consequently, the phenomenological models will be run to estimate corresponding time periods. Laboratory experiments for mechanistic or validation studies are not expected to exceed a 5-year time period. If specific data are required for older (aged) materials (5-50+ years) cores from existing structures will be collected and analyzed.

\subsection{Reference Case Outputs}

The parameters required for PA modeling are the reference case outputs for the CBP experimental and phenomenological modeling efforts. These parameters are typically chemical, hydraulic, and physical properties of the engineered barrier materials and of the barriers themselves and evolution of the properties as a function of time, influx of chemicals and physical conditions that modify the properties. Examples of important properties for cementitious 
barriers include: bulk composition, mineralogy, hydraulic conductivity, solubilities and diffusivities of the matrix phases and contaminant species (leaching properties), porosity and pore size distribution, moisture retention curves (function of pore size distribution and pore structure), bulk density and particle density.

\subsection{Reference Case Cementitious Materials}

Three types of cementitious materials were selected as reference cases. Each of the reference case materials have been used as barriers in actual waste disposal units. These materials are listed below:

- Reinforced Concrete (carbon steel rebar with three inch cover)

o Type I/II Binary Blend (portland cement + blast furnace slag binder)

o Type I/II Ternary Blend (portland cement + blast furnace slag + Class F fly ash binder)

o Type V Sulfate Resistant Quaternary Blend (portland cement + slag + Class F fly ash + silica fume binder)

- Flowable, Stable (zero-bleed) Infill/Back Fill Grout

o Three chemically reducing ternary blends

- High water to cementitious material ratio

- Medium water to cementitious material ratio

- Low water to cementitious material ratio with $3 / 8$ inch stone and sand

o Non reducing binary blend

- Low water to cementitious material ratio with $3 / 8$ inch stone and sand

- Salt waste form.

These materials are described in more detail in Tables 1 to 3, respectively.

\subsection{Reference Disposal and Storage Units}

The CBP reference case materials have been used in actual low-level waste (LLW) disposal units in the DOE complex or in commercial nuclear industry process/storage units. Three reference case configurations are listed below:

a) Cementitious low-level salt waste form in a reinforced concrete disposal vault.

b) Reinforced concrete vault containing a carbon steel high-level waste tank filled with a chemically and structurally stabilizing cementitious grout and low-level waste residuals.

c) Reinforced concrete spent nuclear fuel basis with a stainless steel liner.

Schematic illustrations of the two disposal units and of the spent fuel basin are provided in Figures 3-5. 


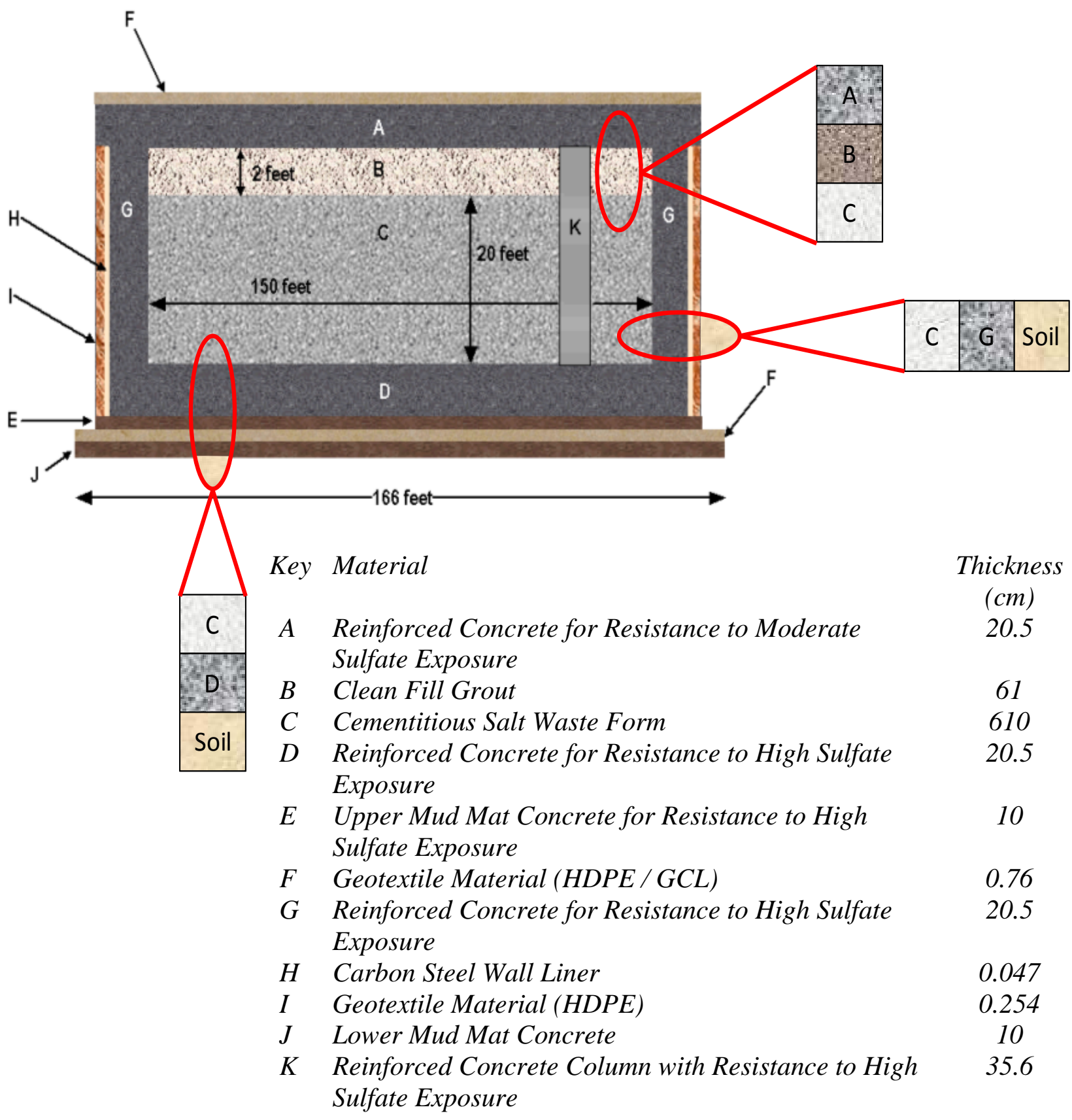

Figure 3. Schematic Illustration of a Reinforced Concrete Vault Containing a Cementitious Low Activity Waste Form. Examples of Multi-layer Material and Interfaces Relevant to 1-D Mechanistic Studies are Illustrated.

\subsubsection{Cementitious Waste Form in Reinforced Concrete Vault}

A brief description of the reference cementitious waste form disposed of in a concrete vault is provided below: 
- Reinforced concrete vault filled with a monolithic cementitious low-level radioactive salt waste form. The concrete vault also contains carbon steel columns and trusses to support the roof. The vault is filled in layers typically 15 to $30 \mathrm{~cm}$ thick.

- A clean grout cap is placed between the final waste form layer and the top of the vault.

- Upon closure of the disposal facility, which will contain multiple vaults, soil backfill will be placed around vaults constructed on grade and a multi-layer cap will be constructed to limit infiltration. (New vault designs call for the vaults to be constructed below grade.)

- External boundary conditions for the at grade vaults prior to closure include: exposure of the concrete walls and roof to ambient air conditions, for example, free exchange of moisture and air with atmosphere, unsaturated concrete with intermittent wetting, and precipitation diverted away from waste form. The base slab will be exposed to unsaturated soil.

- Internal boundary conditions for the vault walls and base slab are a function of exposure to the salt waste form. The waste form is a highly alkaline material with a very high sulfate content and is therefore a potential source of chemicals that are known to degrade concrete.

- External boundary conditions for the concrete vault after closure include: contact with native soil (sand and clay) with very low, intermittent infiltration and unsaturated moisture content controlled by balance of capillary pressures and pore water-vapor equilibrium that is a function of pore space relative humidity.

- Internal boundary conditions for the vault walls and base slab are a function of exposure to the salt waste form (same as above).

For this system, the CBP will conduct research to improve the understanding of degradation mechanisms and material evolution as a function of long times and develop algorithms that link degradation to changes in hydraulic properties of the cementitious barriers which can be used in the PA models.

\subsubsection{Closed High-Level Waste Tank:}

A brief description of the reference closed carbon steel high-level waste tank surrounded by a concrete vault and filled with a cementitious grout is provided below:

- Carbon steel liner (HLW tank) in a reinforced concrete vault will be filled with a cementitious grout to physically stabilize the structure and prevent collapse and to also chemically stabilize residual waste and contaminants. The annulus space between tank and concrete vault will also be filled with cementitious grout.

- One or more grout formulations will be used to fill the tank. A chemically reducing formulation (containing blast furnace slag) will be used for grout in contact with waste residuals.

- Tanks typically contain metal piping (e.g., cooling coils) and process equipment (e.g., pumps) which will also be filled with grout where practical. 
- Closure includes backfill in some cases and coverage with multi-layer cap to limit infiltration.

- Each engineered barrier has a unique set of boundary conditions. For example, the external boundary conditions for the concrete vault are determined by the surrounding soil with a low, intermittent infiltration and unsaturated moisture content controlled by the balance of capillary pressures and pore water-vapor equilibrium and atmospheric exchange by gas diffusion. For the purposes of estimating the consequences over long performance times, the interfaces between the annulus grout and steel tank and the fill grout and the steel piping in the tank will be assumed to be similar to the interfaces between the reinforcing steel in the vault concrete and the concrete itself.

For this system, the CBP will conduct research to improve the understanding of degradation mechanisms and material evolution as a function of soil saturation, episodic events that may create fast pathways, i.e., cracking and its effect on hydraulic and leaching performance.

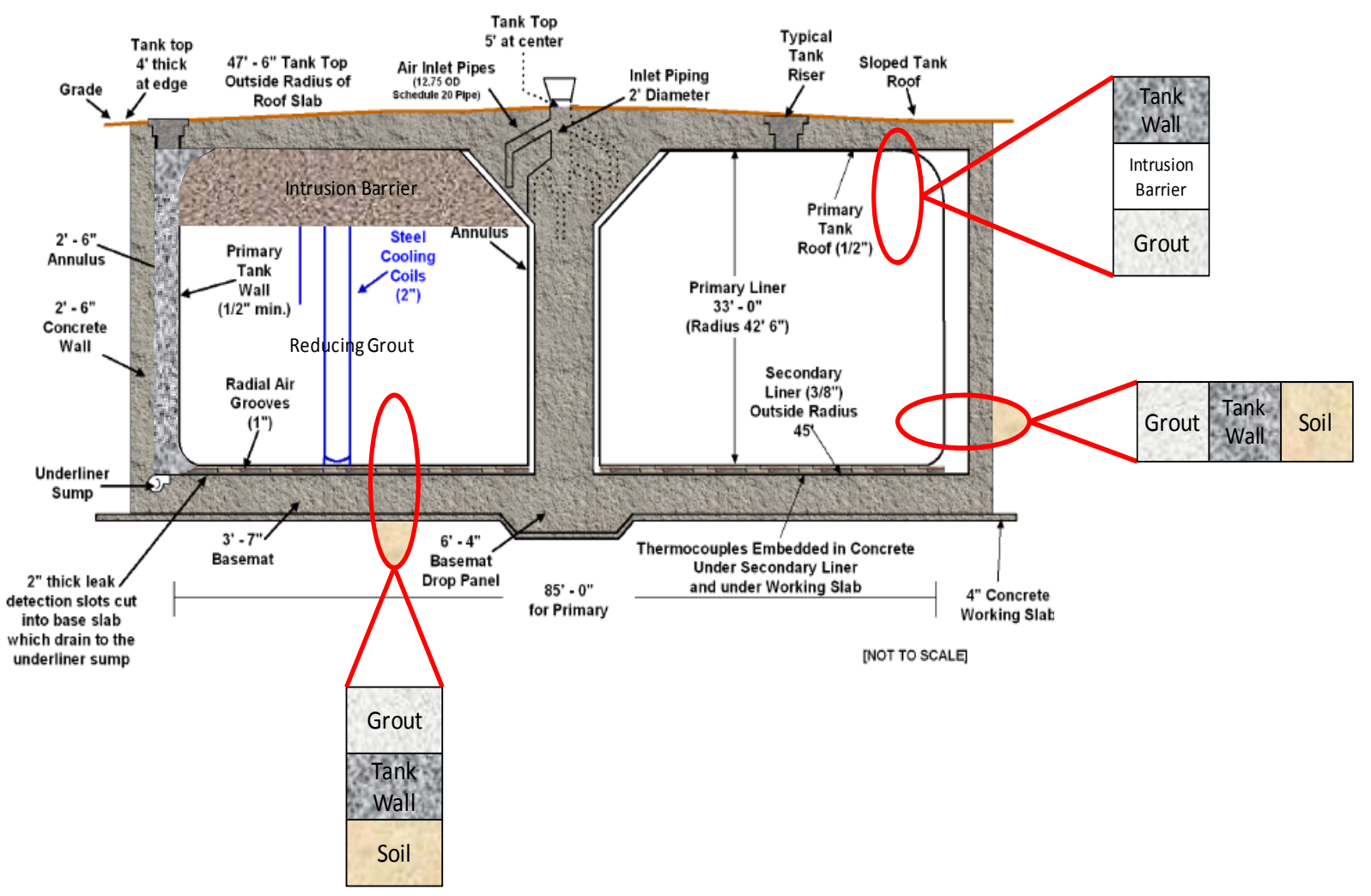

Figure 4. Schematic Illustration of a Closed High-level Waste Tank (Carbon Steel Tank in a Reinforced Concrete Vault) Containing a Cementitious Grout Fill. Examples of Multi-layer Material and Interfaces Relevant to 1-D Mechanistic Studies are Illustrated. 


\subsubsection{Spent Fuel Basin}

A brief description of the reference case for a stainless steel-lined spent fuel basin is provided below:

- Below grade stainless steel-lined, reinforced concrete basin filled with borated water that results in approximately $6 \mathrm{~m}(20 \mathrm{ft})$ of hydraulic head on the basin.

- Internal boundary conditions for the reinforced concrete include complete saturation (water) of concrete pores with water containing borate.

- External boundary conditions include contact with saturated soil.

For this system, the development of through wall cracks due to initial conditions, construction joint failure, or post construction settlement and the resulting impact on flow and transport are of primary interest.

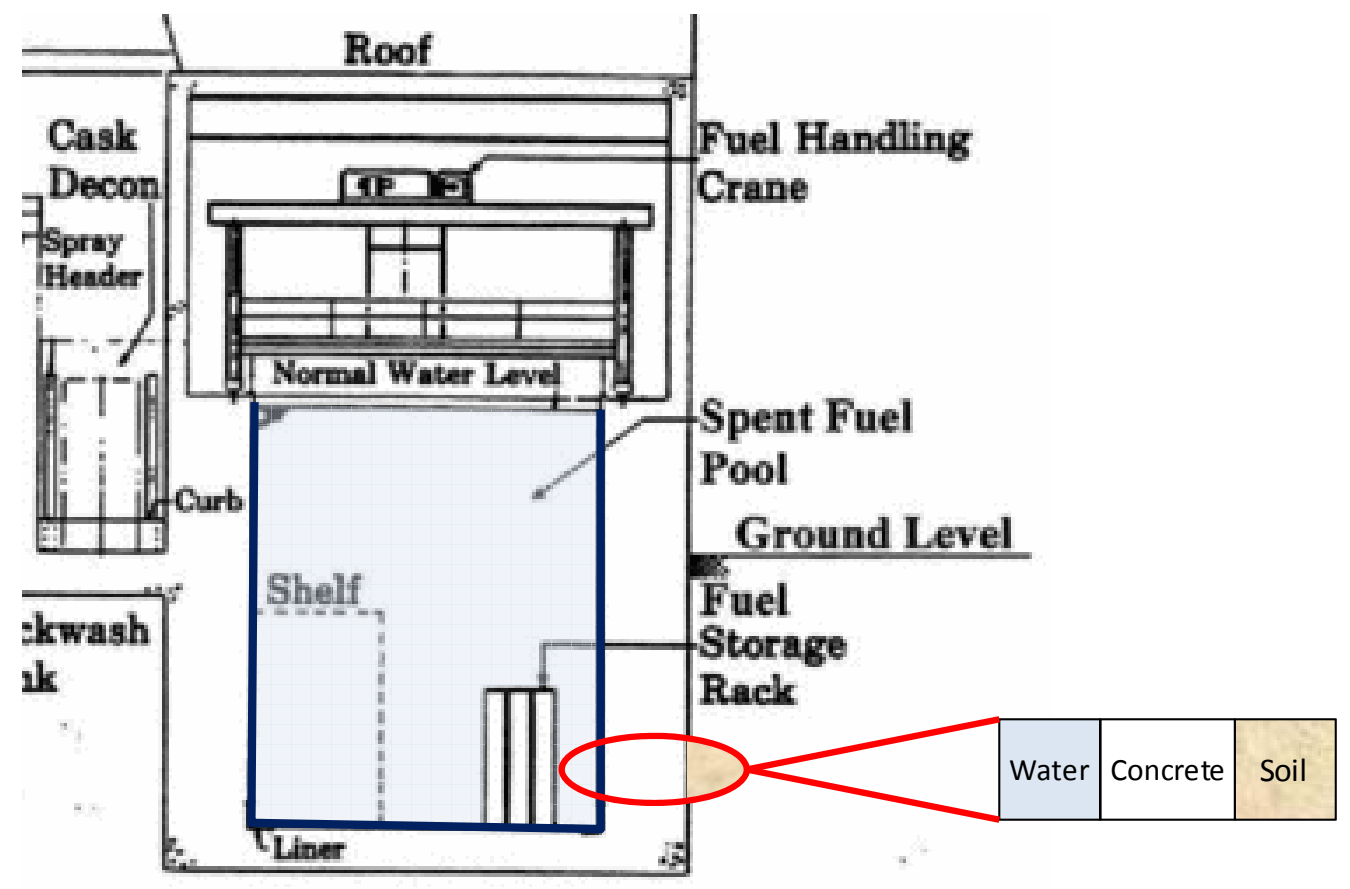

Figure 5. Schematic Dagram of Spent Fuel Pool During Operations. Examples of Multilayer Material and Interfaces Relevant to 1-D Mechanistic Studies are Illustrated [7]

\subsection{BOUNDARY CONDITIONS AND INTERFACES}

The processes at interfaces between adjacent materials with different properties are of great significance, as reactions may occur that can have both beneficial as well as detrimental effects. This to a large extent relates to the gradients in different constituents and properties between the 
adjacent matrices. When there is a gradient between two matrices, diffusion will proceed to reduce the gradient. For this process to occur a transport medium is necessary. Gas phase transport is important for some species, but reaction of gas with dry solid is usually very slow. However, the combination of gas phase diffusion of reactive species $\left(\mathrm{CO}_{2}\right.$ and $\left.\mathrm{O}_{2}\right)$ in a moist environment is a condition that will speed up chemical reactions. The degree of relative saturation has an important impact on transport. Three regimes can be described: (i) a continuous gas phase and discontinuous liquid phase where only gas phase diffusion occurs; (ii) both liquid and gas phases are continuous and diffusion occurs in both phases; and (iii) a continuous liquid phase is present and the gas phase is discontinuous and only liquid phase diffusion occurs.

The most common gradients are $\mathrm{pH}$ gradients, redox gradients, salt gradients and, obviously, the gradients of radionuclide concentrations within the cement stabilized grout. The reactions at interfaces are quite complex, as over a relatively small distance very substantial changes in solubility controlling conditions occur. Understanding these processes is helpful to decide whether such reactive zones play an active role in the transport of substances across an interface.

\subsection{Cementitious Waste - Concrete}

The interface boundary between cement stabilized waste and concrete is characterized by a gradient in soluble salts and depending on the nature of the cement used a redox gradient. Different pore structures amongst the two materials also can result in capillary suction from one to the other material across the interface. In the grout substances may be present that can have a detrimental effect on concrete (like sulfates) or chlorides. If there is a void between concrete and grout, then the carbonation/oxidation will proceed faster in the grout than in the concrete. The rate of front movement is of great relevance for the mobility of different elements.

\subsection{Concrete - Soil}

The interface between concrete and clay barrier and/or soil is characterized by a large $\mathrm{pH}$ gradient. The consequences are remineralization reactions, which depending on the nature of the soil can have surface effects on the concrete. Organic matter from soil interacts with the concrete and can potentially mobilize constituents. As long as the monolithic product remains intact the affected layer is generally limited. Concrete exposed to a moist soil atmosphere will carbonate faster then when exposed to the atmosphere, as the $\mathrm{CO}_{2}$ concentration in the soil gas phase is generally higher than the $\mathrm{CO}_{2}$ level in the atmosphere. This has to do with the degradation of organic matter continuously taking place in soil. Concrete exposed to environmental conditions is only slowly carbonated, unlike the much more porous Roman cements used to construct aquaducts. The ancient pozzolans (TRAS) used have a rather high porosity, which allows carbonation to penetrate deeper. Lumps of Roman cement tested for trace element behavior were found to be fully carbonated to the core (depth of some $10 \mathrm{~cm}$ ) in some 2000 years (ECRICEM II, 2008).

\subsection{Additional barriers}

Additional barriers between grout and surroundings may be steel linings or other additional barriers like High Density Polyethylene Liners. These will form an effective barrier, until the 
lining fails, which at a time scale of 1000's of years may happen. Corrosion of the barrier will be dependent on the interfacial chemistry. The modeling must assume failure at some point in time.

\subsection{DISCUSSION AND CONCLUSIONS}

Each reference case includes the physical geometry of the engineered system, materials of construction (including wastes and contaminants where applicable), and environmental interfaces. In addition, the description of each system includes a scenario which with multiple reference states over defined time intervals:

(i) Initial construction,

(ii) Operations

(iii) Closure (with maintenance) and

(iv) Closure (post-maintenance).

The close state may also have multiple evolutionary states, which include fast pathways or other features that will require consideration in the performance modeling.

Initial definition of the reference cases is focused on a single reference state, i.e., closure (postmaintenance) for waste management units, or operations for operating/storage units. For the purpose of developing algorithms that predict changes in parameters as a function of time and conditions, each reference case was selected to have a plausible system configuration and set of characteristics. However, the reference disposal units are not defined to represent a specific field case. This allows for development and testing over a range of field conditions that cover those encountered across the DOE complex.

Each reference case is a simplification of the actual expected disposal or storage unit and is a conceptual model of a unit. The definition of each reference case is expected to evolve over time as more knowledge is obtained and model uncertainties are addressed in addition to parameter and numerical uncertainties. 


\subsection{REFERENCES}

1. C. A. Langton, et. al., 2008. "Partnership for the Development of Next Generation Simulation Tools to Evaluate Cementitious Barriers and Materials Used in Nuclear Applications" DOE Waste Management Symposium, February 2008, Phoenix, AZ.

2. U.S. Department of Energy Office of Environmental Management, September 2007, Technology Engineering Road Map: Reducing Technical Risk and Uncertainty in the EM Program, U.S. DOE, Washington DC, www.em.doe.gov.

3. K. L. Dixon, J. Harbour, and M. A. Phifer. 2008. "Hydraulic and Physical Properties of Saltstone Grouts and Vault Concretes," SRNL-STI-2008-00421, Revision 0, November 2008, Savannah River Nuclear Solutions, LLC, Savannah River Site, Aiken, SC 29808.

4. M. A. Phifer, M. R. Millings, and G. P. Flach, "Hydraulic Property Data Package for the EArea and Z-Area Soils, Cementitious Materials, and Waste Zones," WSRC-STI-2006-00198, Revision 0, September 2006, Washington Savannah River Company, Savannah River Site, Aiken, SC 29808.

5. K. L. Dixon and M. A. Phifer, 2007. "Hydraulic and Physical Properties of Tank Grouts and Base Mat Surrogate Concrete for FTF Closure, WSRC-STI-2007-00369 Revision 0, October 2007, Washington Savannah River Company, Savannah River Site, Aiken, SC 29808.

6. K. L. Dixon and M. A. Phifer, 20007. "Cementitious Material Selection for the Future Component-In-Grout Waste Disposals," WSRC-STI-2007-00207, Revision 0, December 2007, Washington Savannah River Company, Savannah River Site, Aiken, SC 29808.

7. J. Philip, 2007. Personal Communication, US Nuclear Regulatory Commission.

8. D. I. Kaplan and J. M. Coates, 2007. "Partitioning of Dissolved Radionuclides to Concrete Under Scenarios Appropriate for Tank Closure Performance Assessments," WSRC-STI2007-00640, Revision 0, December 21, 2007, Washington Savannah River Company, Savannah River Site, Aiken, SC 29808.

9. D. I. Kaplan, 2006. "Geochemical Data Package for Performance Assessment Calculations Related to the Savannah River Site," WSRC-TR-2006-00004, Revision 0. Fegruary 28, 2006, Washington Savannah River Company, Savannah River Site, Aiken, SC 29808.

10. D. I. Kaplan, K. Roberts, J. Coates, M. Siegfried, and S. Serkiz, "Saltstone and Concrete Interactions with Radionuclides: Sorption $(\mathrm{Kd})$, Desorption, and Reductin Capacity Measurements," SRNS-STI-2008-00045, October 30, 2008, Savannah River Nuclear Solutions, Savannah River Site, Aiken, SC 29808. 
11. Nichols, R. L., Looney, B. B., Flach, G. P., and Rossabi, J., 2000. "Recommendations for Phase II Vadose Zone Characterization and Monitoring at the E-Area Disposal "Slit" Trenches and Mega-Trench (U)," WSRC-TR-2000-00059, February 2000, Westinghouse Savannah River Company, Aiken, South Carolina. 


\subsection{ATTACHMENTS}




\subsection{ATTACHMENT A - REFERENCE CASE MATERIALS AND PHYSICAL} PROPERTIES 
Table A-1. Reference Case Binary, Ternary, and Quaternary Concrete Formulations [3, 4].

\begin{tabular}{|c|c|c|c|}
\hline Ingredient & $\begin{array}{c}\text { Type I/II } \\
\text { Binary Blend } \\
{[3]} \\
\left(\mathbf{k g} / \mathbf{m}^{3}\right) \\
\left(\mathrm{lbs} / \mathrm{yd} \mathbf{d}^{3}\right)\end{array}$ & \begin{tabular}{|c|} 
Type I/II Ternary \\
Blend [4] \\
$\left(\mathrm{kg} / \mathbf{m}^{3}\right)$ \\
$\left(\mathrm{lbs} / \mathrm{yd} \mathbf{d}^{3}\right)$
\end{tabular} & \begin{tabular}{|c|} 
Type V \\
Quaternary Blend [3] \\
$\left(\mathrm{kg} / \mathrm{m}^{3}\right)$ \\
$\left(\mathrm{lbs} / \mathrm{yd}^{3}\right)$
\end{tabular} \\
\hline Type I/II Cement (ASTM C 150) & $\begin{array}{c}239 \\
(419)\end{array}$ & $\begin{array}{c}71.3 \\
(120)\end{array}$ & 0 \\
\hline Type V Cement (ASTM C 150) & 0 & 0 & $\begin{array}{l}133.5 \\
(225)\end{array}$ \\
\hline $\begin{array}{l}\text { Blast Furnace Slag } \\
\text { (ASTM C 989) }\end{array}$ & $\begin{array}{c}158 \\
(278)\end{array}$ & $\begin{array}{c}163 \\
(275)\end{array}$ & $\begin{array}{c}178 \\
(300)\end{array}$ \\
\hline Type F Fly Ash (ASTM C 618) & 0 & $\begin{array}{l}80.1 \\
(135) \\
\end{array}$ & $\begin{array}{l}103.8 \\
(175) \\
\end{array}$ \\
\hline Silica Fume (ASTM C 1240) & 0 & 0 & $\begin{array}{l}29.7 \\
(50)\end{array}$ \\
\hline Quartz Sand (ASTM C 33) & $\begin{array}{c}646 \\
(1133)\end{array}$ & $\begin{array}{l}756.7 \\
(1270)\end{array}$ & $\begin{array}{l}540.7 \\
(911)\end{array}$ \\
\hline $\begin{array}{l}\text { No. } 67 \text { Granite Aggregate } \\
\text { (maximum } 3 / 4 \text { in) (ASTM C 33) }\end{array}$ & $\begin{array}{c}1025 \\
(1798)\end{array}$ & $\begin{array}{l}1038.6 \\
(1750)\end{array}$ & $\begin{array}{c}1098 \\
(1850)\end{array}$ \\
\hline Water (maximum) & $\begin{array}{c}152 \\
268 \\
\text { (32.1gallons) } \\
\end{array}$ & $\begin{array}{c}142.4 \\
240 \\
(28.8 \text { gallons) } \\
\end{array}$ & $\begin{array}{c}168.6 \\
284 \\
\text { (34 gallons) } \\
\end{array}$ \\
\hline $\begin{array}{l}\text { Water to Cementitious Material } \\
\text { Ratio }\end{array}$ & 0.385 & 0.38 & 0.38 \\
\hline $\begin{array}{l}\text { Grace WRDA } 35 \\
(\mathrm{ml} / 100 \mathrm{~kg} \text { cement }+ \text { pozzolan }) \\
(\text { oz/cwt cement }+ \text { pozzolans })\end{array}$ & $\begin{array}{l}32.6 \\
(5.0) \\
\end{array}$ & $\begin{array}{l}32.6 \\
(5.0) \\
\end{array}$ & $\begin{array}{l}32.6 \\
(5.0) \\
\end{array}$ \\
\hline $\begin{array}{l}\text { Grace Darex II } \\
(\mathrm{ml} / 100 \mathrm{~kg} \text { cement }+ \text { pozzolan }) \\
(\text { oz/cwt cement }+ \text { pozzolans })\end{array}$ & $\begin{array}{c}2.6-3.3 \\
(0.4-0.5)\end{array}$ & $\begin{array}{c}2.6-3.3 \\
(0.4-0.5)\end{array}$ & $\begin{array}{c}2.6-3.3 \\
(0.4-0.5)\end{array}$ \\
\hline $\begin{array}{l}\text { Grace Adva } 380 \\
(\mathrm{ml} / 100 \mathrm{~kg} \text { cement }+ \text { pozzolan }) \\
(\text { oz/cwt cement }+ \text { pozzolan })\end{array}$ & $\begin{array}{c}19.6-26.1 \\
(3-4)\end{array}$ & $\begin{array}{c}19.6-26.1 \\
(3-4)\end{array}$ & $\begin{array}{c}19.6-26.1 \\
(3-4)\end{array}$ \\
\hline $\begin{array}{l}\text { Unit Weight }\left(\mathrm{kg} / \mathrm{m}^{3}\right) \\
\left(\mathrm{lbs} / \mathrm{yd}^{3}\right)\end{array}$ & $\begin{array}{c}2220 \\
(3896)\end{array}$ & $\begin{array}{c}2156 \\
(3790)\end{array}$ & $\begin{array}{c}2162 \\
(3795)\end{array}$ \\
\hline $\begin{array}{l}\text { Compressive Strength at } 28 \text { Days } \\
(\mathrm{MPa}) \\
\text { (psi) }\end{array}$ & $\begin{array}{c}27.6 \\
(4000) \\
\end{array}$ & $\begin{array}{c}27.6 \\
(4000)\end{array}$ & $\begin{array}{c}34.5 \\
(5000) \\
\end{array}$ \\
\hline
\end{tabular}


Table A-2. Reference Case Concretes Physical and Hydraulic Property Data [3, 4].

\begin{tabular}{|c|c|c|c|}
\hline Property & $\begin{array}{c}\text { CBP Reference } \\
\text { Type I/II Binary } \\
\text { Blend [3] } \\
\left(\mathbf{k g} / \mathbf{m}^{3}\right) \\
\left(\mathrm{lbs} / \mathrm{yd}^{3}\right) \\
\end{array}$ & $\begin{array}{c}\text { CBP Reference } \\
\text { Type I/II Ternary } \\
\text { Blend [4] } \\
\left(\mathrm{kg} / \mathrm{m}^{3}\right) \\
\left(\mathrm{lbs} / \mathrm{yd}^{3}\right) \\
\end{array}$ & \begin{tabular}{|c|} 
CBP Reference \\
Type V \\
Quaternary Blend [3] \\
$\left(\mathbf{k g} / \mathbf{m}^{3}\right)$ \\
$\left(\mathrm{lbs} / \mathrm{yd}^{3}\right)$ \\
\end{tabular} \\
\hline \multicolumn{4}{|l|}{ Compressive Strength (psi) } \\
\hline 28 Days & 8725 & & 7430 \\
\hline 90 Days & 9430 & & 9280 \\
\hline $\begin{array}{l}\text { Saturated Hydraulic } \\
\text { Conductivity }(\mathrm{cm} / \mathrm{s}) \\
\text { Samples Cured } 28 \text { Days } \\
\text { (log average) }\end{array}$ & $\begin{array}{c}3.1 \mathrm{E}-10 \\
\text { Range } \\
1.1 \mathrm{E}-10 \text { to } 2.1 \mathrm{E}-09\end{array}$ & & $\begin{array}{c}1.1 \mathrm{E}-10 \\
\text { Range } \\
6.0 \mathrm{E}-11 \text { to } 2.8 \mathrm{E}-10\end{array}$ \\
\hline $\begin{array}{l}\text { Intrinsic Permeability (Darcy) } \\
\text { Based on Properties of Tap } \\
\text { Water } \\
\text { (log average) }\end{array}$ & $\begin{array}{c}\text { 3.2E-08 } \\
\text { Range } \\
1.1 \mathrm{E}-08 \text { to } 2.2 \mathrm{E}-07\end{array}$ & & $\begin{array}{c}1.1 \mathrm{E}-08 \\
\text { Range } \\
6.2 \mathrm{E}-09 \text { to } 2.9 \mathrm{E}-08\end{array}$ \\
\hline $\begin{array}{l}\text { Dry Bulk Density }\left(\mathrm{g} / \mathrm{cm}^{3}\right) \\
28 \text { Days } \\
\text { (arithmetic average) }\end{array}$ & $\begin{array}{c}2.24 \\
\text { Range } 2.15 \text { to } 2.31 \\
\end{array}$ & & $\begin{array}{c}2.19 \\
\text { Range } 2.16 \text { to } 2.21 \\
\end{array}$ \\
\hline $\begin{array}{l}\text { Particle Density }\left(\mathrm{g} / \mathrm{cm}^{3}\right) \\
28 \text { Days } \\
\text { (arithmetic average) }\end{array}$ & $\begin{array}{c}2.53 \\
\text { Range } 2.44 \text { to } 2.58 \\
\end{array}$ & & $\begin{array}{c}2.48 \\
\text { Range } 2.39 \text { to } 2.50 \\
\end{array}$ \\
\hline $\begin{array}{l}\text { Porosity (volume fraction) } \\
28 \text { Days } \\
\text { (arithmetic average) }\end{array}$ & $\begin{array}{c}0.11 \\
\text { Range } 0.10 \text { to } 0.12 \\
\end{array}$ & & $\begin{array}{c}0.12 \\
\text { Range } 0.08 \text { to } 0.13\end{array}$ \\
\hline $\begin{array}{l}\text { Moisture Retention Curves } \\
\text { Over Pressure Range } 102 \text { to } \\
15,296 \mathrm{~cm} \mathrm{H}_{2} \mathrm{O}(0.1 \text { to } 15 \text { bars })\end{array}$ & Figure A-1 & & Figure A-2 \\
\hline Characterization Curves & Figure A-3 & & Figure A-4 \\
\hline \multicolumn{4}{|l|}{$\begin{array}{l}\text { Van Genuchten Transport } \\
\text { Parameters }\end{array}$} \\
\hline$\theta_{\mathrm{s}}\left(\mathrm{cm}^{3} / \mathrm{cm}^{-3}\right)$ & 0.121 & & 0.124 \\
\hline$\theta_{\mathrm{r}}\left(\mathrm{cm}^{3} / \mathrm{cm}^{-3}\right)$ & 0.115 & & 0.119 \\
\hline$\alpha(1 / \mathrm{cm})$ & 0.054 & & 0.006 \\
\hline $\mathrm{n}$ & 1.27 & & 1.65 \\
\hline $\mathrm{m}$ & 0.2099 & & 0.3951 \\
\hline
\end{tabular}


Reference Cases for Use in the Cementitious Barriers Partnership Project

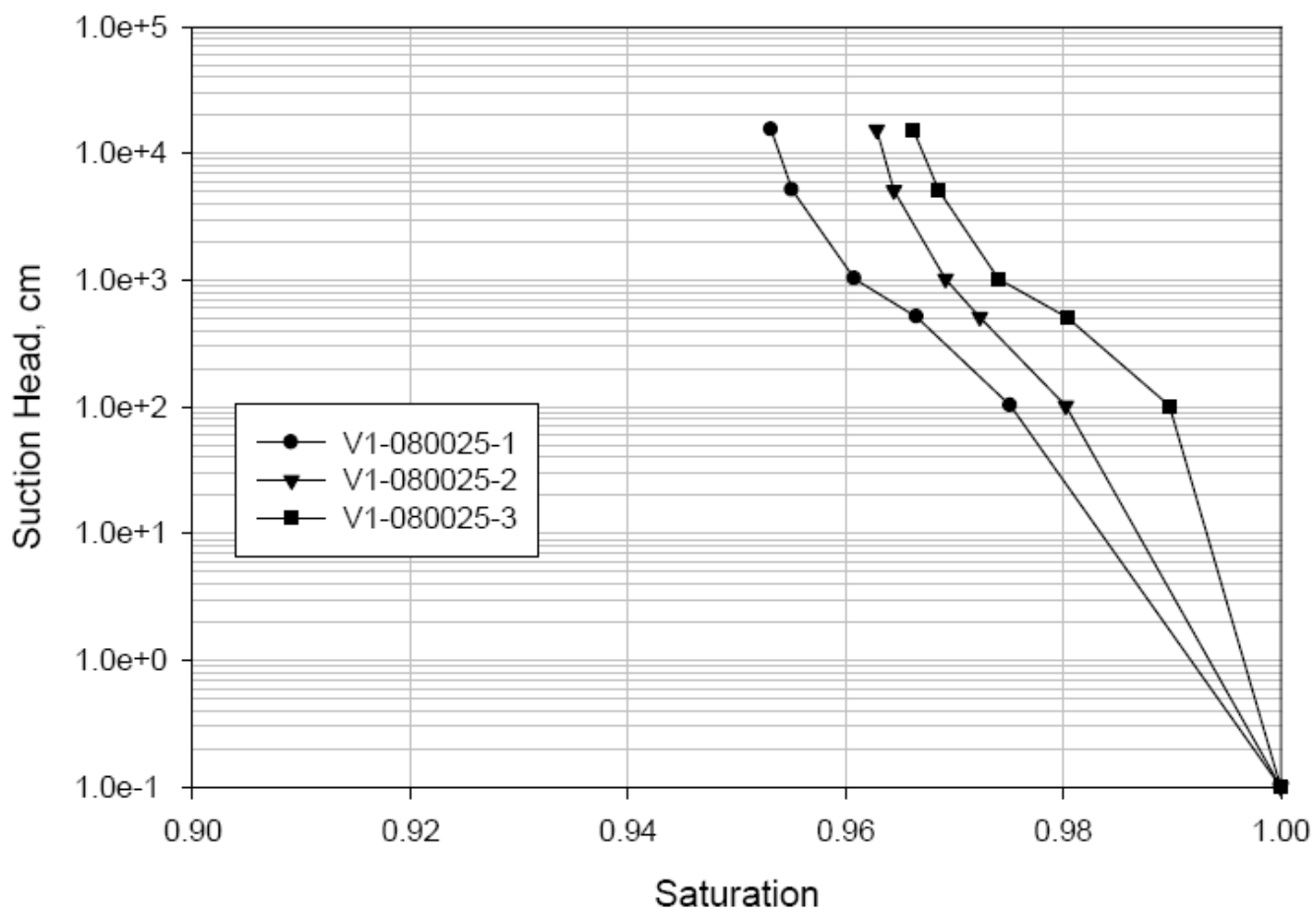

Figure A-1. Moisture retention curves for the 28 day binary concrete samples (Vault 1/4).

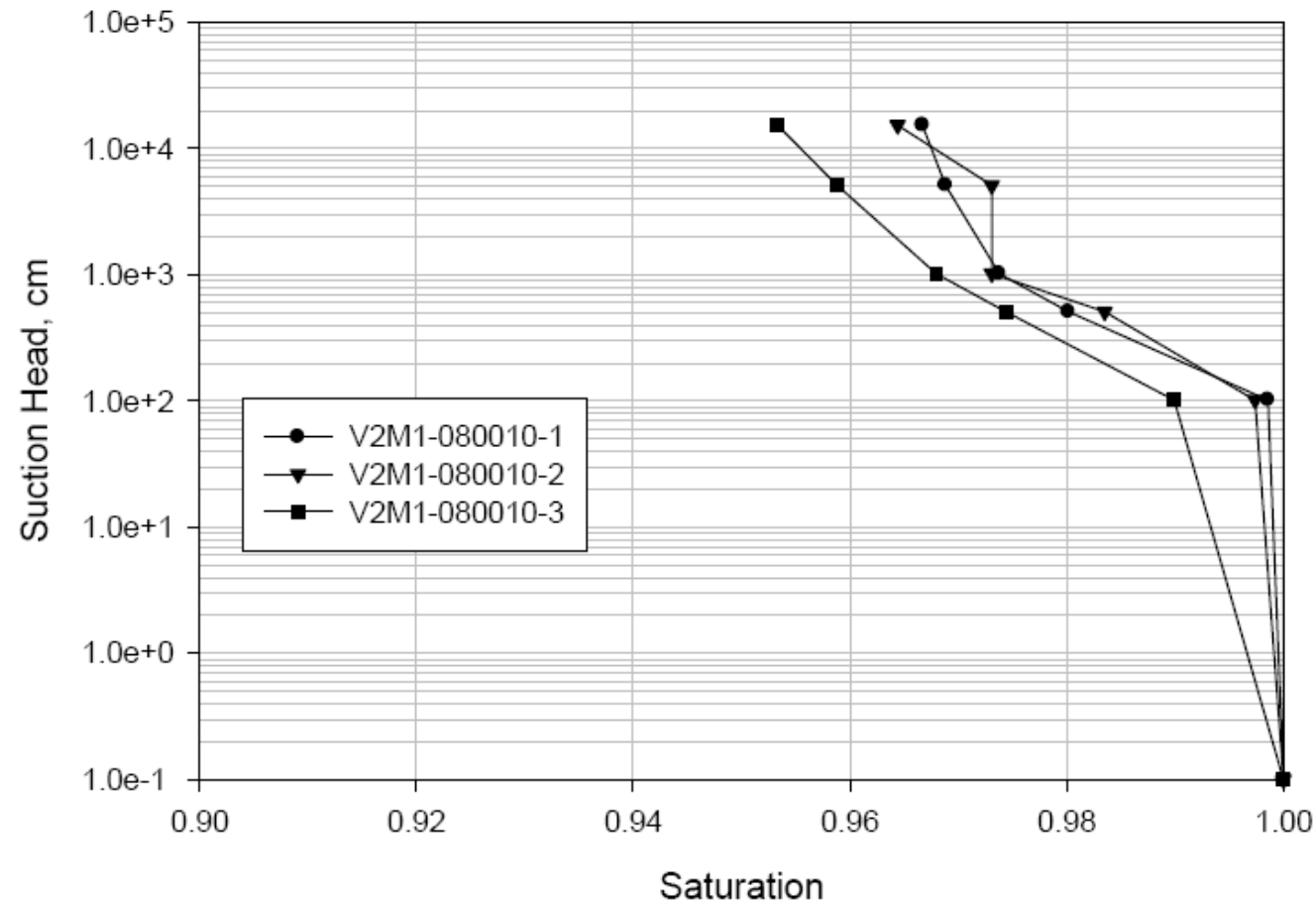

Figure A-2. Moisture retention curves for the 28 day quaternary concrete samples (Vault 2). 


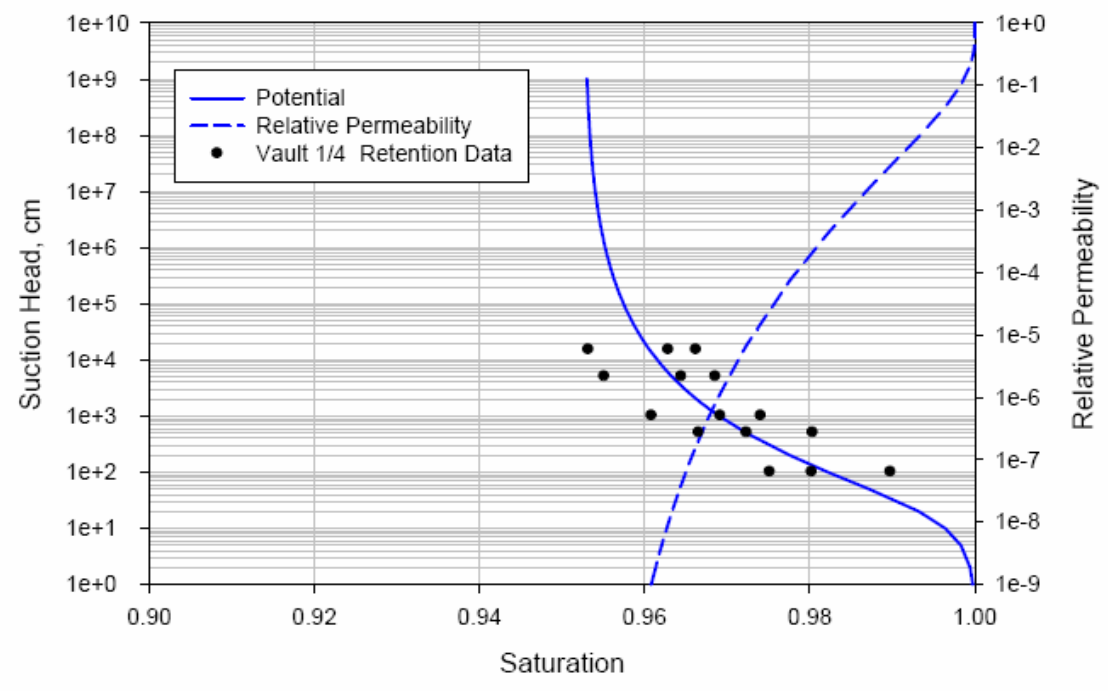

Figure A-3. Characteristic Curves for Binary Concrete based on 28 day curing.

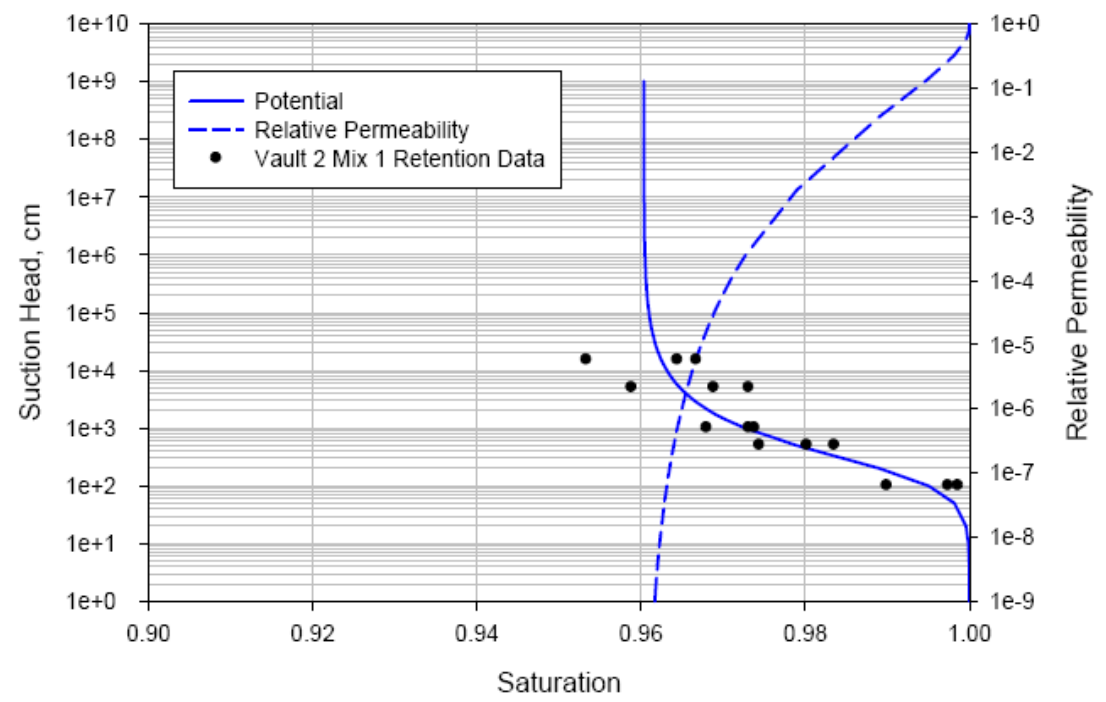

Figure A-4. Characteristic Curves for Quaternary Concrete based on 28 day curing. 
6.2 ATTACHMENT B - REFERENCE CASE FILL MATERIALS AND PHYSICAL PROPERTIES 
Table B-1. Reference Case Fill Grout Formulations.

\begin{tabular}{|c|c|c|c|c|}
\hline Ingredient & $\begin{array}{c}\text { Type I/II } \\
\text { Ternary } \\
\text { Blend [5] } \\
\left(\mathbf{k g} / \mathbf{m}^{3}\right) \\
\left(\mathrm{lbs}_{\mathbf{y}} \mathrm{yd}^{3}\right) \\
\end{array}$ & $\begin{array}{c}\text { Type I/II } \\
\text { Ternary } \\
\text { Blend } 2 \text { [5] } \\
\left(\mathbf{k g} / \mathbf{m}^{3}\right) \\
\left(\mathrm{lb} / \mathrm{yd}^{3}\right) \\
\end{array}$ & $\begin{array}{c}\text { Type I/II } \\
\text { Ternary } \\
\text { Blend } 3 \text { [5] } \\
\left(\mathbf{k g} / \mathbf{m}^{3}\right) \\
\left(\mathrm{lbs} / \mathrm{yd} \mathbf{d}^{3}\right) \\
\end{array}$ & $\begin{array}{c}\text { Type I/II } \\
\text { Binary } \\
\text { Blend [6] } \\
\left(\mathrm{kg} / \mathrm{m}^{3}\right) \\
\left(\mathrm{lbs} / \mathrm{yd}^{3}\right) \\
\end{array}$ \\
\hline $\begin{array}{l}\text { Type I/II Cement } \\
\text { (ASTM C 150) }\end{array}$ & $\begin{array}{l}44.5 \\
(75) \\
\end{array}$ & $\begin{array}{l}109.8 \\
(185)\end{array}$ & $\begin{array}{l}109.8 \\
(185)\end{array}$ & $\begin{array}{c}267 \\
(450) \\
\end{array}$ \\
\hline $\begin{array}{l}\text { Grade } 100 \text { Blast Furnace Slag } \\
\text { (ASTM C 989) }\end{array}$ & $\begin{array}{l}124.6 \\
(210) \\
\end{array}$ & $\begin{array}{l}154.3 \\
(260)\end{array}$ & $\begin{array}{l}154.3 \\
(260)\end{array}$ & 0 \\
\hline $\begin{array}{l}\text { Type F Fly Ash } \\
\text { (ASTM C 618) }\end{array}$ & $\begin{array}{l}222.6 \\
(375)\end{array}$ & $\begin{array}{l}344.2 \\
(580)\end{array}$ & $\begin{array}{l}504.5 \\
(850)\end{array}$ & $\begin{array}{c}267 \\
(450)\end{array}$ \\
\hline $\begin{array}{l}\text { Quartz Sand } \\
\text { (ASTM C 33) }\end{array}$ & $\begin{array}{c}1365 \\
(2300) \\
\end{array}$ & $\begin{array}{l}1118.7 \\
(1885) \\
\end{array}$ & $\begin{array}{l}559.1 \\
(942)\end{array}$ & $\begin{array}{l}746.6 \\
(1258) \\
\end{array}$ \\
\hline $\begin{array}{l}\text { No. } 8 \text { Granite Aggregate } \\
\text { (maximum } 3 / 8 \text { in) (ASTM C } \\
\text { 33) }\end{array}$ & 0 & 0 & $\begin{array}{l}561.5 \\
(946)\end{array}$ & $\begin{array}{l}741.9 \\
(1250)\end{array}$ \\
\hline $\begin{array}{l}\text { Water (maximum) }\left(\mathrm{kg} / \mathrm{m}^{3}\right) \\
\left(\mathrm{lbs} / y d^{3}\right)\end{array}$ & $\begin{array}{c}297 \\
501 \text { (60 } \\
\text { gallons) }\end{array}$ & $\begin{array}{c}297 \\
501(60 \\
\text { gallons) }\end{array}$ & $\begin{array}{c}302 \\
509(61 \\
\text { gallons) }\end{array}$ & $\begin{array}{c}207.7 \\
350(42 \\
\text { gallons })\end{array}$ \\
\hline $\begin{array}{l}\text { Water to Cementitious } \\
\text { Material Ratio }\end{array}$ & 0.76 & 0.49 & 0.39 & 0.39 \\
\hline $\begin{array}{l}\text { Viscosity Modifier (Welan } \\
\text { Gum) Kelco-Crete }\left(\text { grams } / \mathrm{m}^{3}\right) \\
\left(\text { grams } / y d^{3}\right)\end{array}$ & $\begin{array}{l}360 \\
(275)\end{array}$ & $\begin{array}{l}283 \\
(216)\end{array}$ & $\begin{array}{l}283 \\
(216)\end{array}$ & 0 \\
\hline $\begin{array}{l}\text { High Range Water Reducer } \\
(\mathrm{HRWR})\left(\mathrm{L} / \mathrm{m}^{3}\right) \\
\left(\mathrm{fl} \mathrm{oz} / \mathrm{yd}^{3}\right)\end{array}$ & $\begin{array}{l}3.48 \\
90 * \\
\end{array}$ & $\begin{array}{l}2.88 \\
54 * *\end{array}$ & $\begin{array}{c}2.88 \\
54 * * *\end{array}$ & $\begin{array}{c}2.88-2.707 \\
54-70\end{array}$ \\
\hline Sodium Thiosulfate (optional) & $\begin{array}{l}1.25 \\
(2.1) \\
\end{array}$ & $\begin{array}{l}1.25 \\
(2.1)\end{array}$ & $\begin{array}{l}1.25 \\
(2.1)\end{array}$ & 0 \\
\hline $\begin{array}{l}\text { Set Regulator (W. R. Grace } \\
\text { Recover }\left(f l o z / y d^{3}\right)\end{array}$ & as needed & as needed & as needed & as needed \\
\hline $\begin{array}{l}\text { Unit Weight }\left(\mathrm{kg} / \mathrm{m}^{3}\right) \\
\left(\mathrm{lbs} / \mathrm{yd}^{3}\right)\end{array}$ & $\begin{array}{c}1972 \\
(3461) \\
\end{array}$ & $\begin{array}{c}1952 \\
(3426) \\
\end{array}$ & $\begin{array}{c}2104 \\
(3692) \\
\end{array}$ & $\begin{array}{c}2141 \\
(3758) \\
\end{array}$ \\
\hline $\begin{array}{l}\text { Compressive strength at } 28 \\
\text { Days } \\
\text { MPa } \\
\text { (psi) }\end{array}$ & $\begin{array}{c}27.6 \\
(4000)\end{array}$ & $\begin{array}{l}27.6 \\
(4000)\end{array}$ & $\begin{array}{l}34.5 \\
(5000)\end{array}$ & $\begin{array}{c}27.6 \\
(4000)\end{array}$ \\
\hline
\end{tabular}

* W. R. Grace Adva flow ** Sika ViscoCrete $2100 * * *$ W. R. Grace Advaflex 
Table B-2. Physical and Hydraulic Property Data for Reference Case Flowable Fill Grout Formulations [5, 6].

\begin{tabular}{|c|c|c|c|c|}
\hline Property & $\begin{array}{c}\text { Type I/II } \\
\text { Ternary Blend } \\
{[5]} \\
\left(\mathbf{k g} / \mathbf{m}^{3}\right) \\
\left(\mathrm{lbs} / \mathrm{yd} d^{3}\right)\end{array}$ & $\begin{array}{c}\text { Type I/II } \\
\text { Ternary Blend } 2 \\
{[5]} \\
\left(\mathbf{k g} / \mathbf{m}^{3}\right) \\
\left(\mathbf{l b} / \mathrm{yd}^{3}\right)\end{array}$ & \begin{tabular}{|c|} 
Type I/II \\
Ternary Blend 3 \\
{$[5]$} \\
$\left(\mathrm{kg} / \mathrm{m}^{3}\right)$ \\
$\left(\mathrm{lbs} / \mathrm{yd} \mathbf{d}^{3}\right)$
\end{tabular} & $\begin{array}{c}\text { Type I/II Binary } \\
\text { Blend [6] } \\
\left(\mathbf{k g} / \mathrm{m}^{3}\right) \\
\left(\mathrm{lbs} / \mathrm{yd} \mathbf{d}^{3}\right)\end{array}$ \\
\hline \multicolumn{5}{|l|}{ Compressive Strength (psi) } \\
\hline $\begin{array}{l}28 \text { Days Average of } 2 \\
\text { Samples }\end{array}$ & $\begin{array}{c}1,710 \\
\text { Range } \\
1,660 \text { to } 1,760 \\
\end{array}$ & $\begin{array}{c}3,550 \\
\text { Range } \\
3,500 \text { to } 3,610 \\
\end{array}$ & $\begin{array}{c}2,885 \\
\text { Range } \\
2,280 \text { to } 3,490 \\
\end{array}$ & $\begin{array}{c}4,680 \\
\text { Range } \\
4,420 \text { to } 4,830\end{array}$ \\
\hline 90 Days & $\begin{array}{c}2,275 \\
\text { Range } \\
2,250 \text { to } 2,300\end{array}$ & $\begin{array}{c}5,295 \\
\text { Range } \\
5,160 \text { to } 5,430\end{array}$ & $\begin{array}{c}4,840 \\
\text { Range } \\
4,600 \text { to } 5,080\end{array}$ & $\begin{array}{c}1,640 \\
\text { Range } \\
7,520 \text { to } 7,700\end{array}$ \\
\hline 180 Days & 2,410 & NA & NA & NA \\
\hline $\begin{array}{l}\text { Saturated Hydraulic } \\
\text { Conductivity }(\mathrm{cm} / \mathrm{s}) \\
\text { Samples Cured } 28 \text { Days } \\
\text { (arithmetic average) }\end{array}$ & $\begin{array}{c}3.6 \mathrm{E}-08 \\
\text { Range } \\
1.0 \mathrm{E}-08 \text { to } 8.5 \mathrm{E}- \\
08\end{array}$ & $\begin{array}{c}8.9 \mathrm{E}-09 \\
\text { Range } \\
8.2 \mathrm{E}-09 \text { to } 9.5 \mathrm{E}-09\end{array}$ & \begin{tabular}{|c}
$6.6 \mathrm{E}-09$ \\
Range \\
$5.5 \mathrm{E}-09$ to $8.1 \mathrm{E}-$ \\
09
\end{tabular} & $\begin{array}{c}3.6 \mathrm{E}-08 \\
\text { Range } \\
1.5 \mathrm{E}-08 \text { to } 7.2 \mathrm{E}- \\
08\end{array}$ \\
\hline \multicolumn{5}{|l|}{$\begin{array}{l}\text { Intrinsic Permeability } \\
\text { (darcy) } \\
\text { Based on Properties of Tap } \\
\text { Water (log average) }\end{array}$} \\
\hline $\begin{array}{l}\text { Dry Bulk Density }\left(\mathrm{g} / \mathrm{cm}^{3}\right) \\
28 \text { Days (arithmetic ave.) }\end{array}$ & $\begin{array}{c}1.81 \\
\text { Range } \\
1.80 \text { to } 1.86\end{array}$ & $\begin{array}{c}1.86 \\
\text { Range } \\
1.84 \text { to } 1.88\end{array}$ & $\begin{array}{c}1.96 \\
\text { Range } \\
1.92 \text { to } 2.06\end{array}$ & $\begin{array}{c}2.01 \\
\text { Range } \\
1.99 \text { to } 2.04\end{array}$ \\
\hline \multicolumn{5}{|l|}{$\begin{array}{l}\text { Particle Density }\left(\mathrm{g} / \mathrm{cm}^{3}\right) \\
28 \text { Days (arithmetic ave.) }\end{array}$} \\
\hline $\begin{array}{l}\text { Porosity (volume fraction) } 28 \\
\text { Days } \\
\text { Water Exchangeable } \\
\text { Porosity (arithmetic ave.) }\end{array}$ & $\begin{array}{c}0.266 \\
\text { Range } \\
0.219 \text { to } 0.278\end{array}$ & $\begin{array}{c}0.220 \\
\text { Range } \\
0.190 \text { to } 0.250\end{array}$ & $\begin{array}{c}0.209 \\
\text { Range } \\
0.186 \text { to } 0.225\end{array}$ & $\begin{array}{c}0.167 \\
\text { Range } \\
0.137 \text { to } 0.216\end{array}$ \\
\hline $\begin{array}{l}\text { Moisture Retention Curves } \\
\text { Over Pressure Range } 102 \text { to } \\
15,296 \mathrm{~cm} \mathrm{H}_{2} \mathrm{O}(0.1 \text { to } 15 \\
\text { bars })\end{array}$ & & & Figure B-4 & \\
\hline Characteristic Curves & Figure B-1 & Figure B-2 & Figure B-3 & \\
\hline \multicolumn{5}{|l|}{$\begin{array}{l}\text { Van Genuchten Transport } \\
\text { Parameters }\end{array}$} \\
\hline \multicolumn{5}{|l|}{$\theta_{\mathrm{s}}\left(\mathrm{cm}^{3} / \mathrm{cm}^{-3}\right)$} \\
\hline \multicolumn{5}{|l|}{$\theta_{\mathrm{r}}\left(\mathrm{cm}^{3} / \mathrm{cm}^{-3}\right)$} \\
\hline \multicolumn{5}{|l|}{$\alpha(1 / \mathrm{cm})$} \\
\hline \multicolumn{5}{|l|}{$\mathrm{n}$} \\
\hline $\mathrm{m}$ & & & & \\
\hline
\end{tabular}




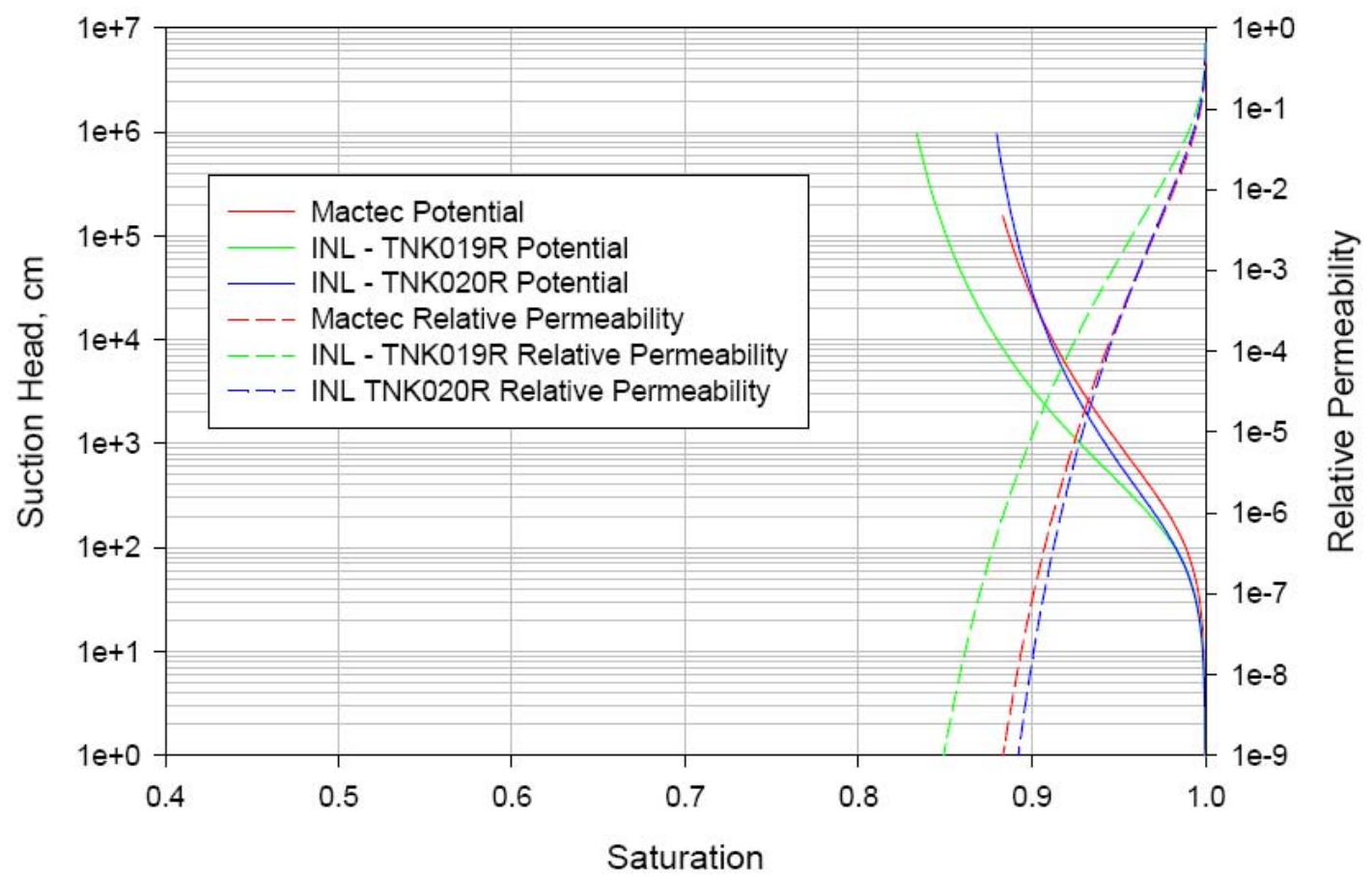

Figure B-1. Comparison of characteristic curves for Type I/II Ternary Blend Reducing Grout using measurements from various sources [5].

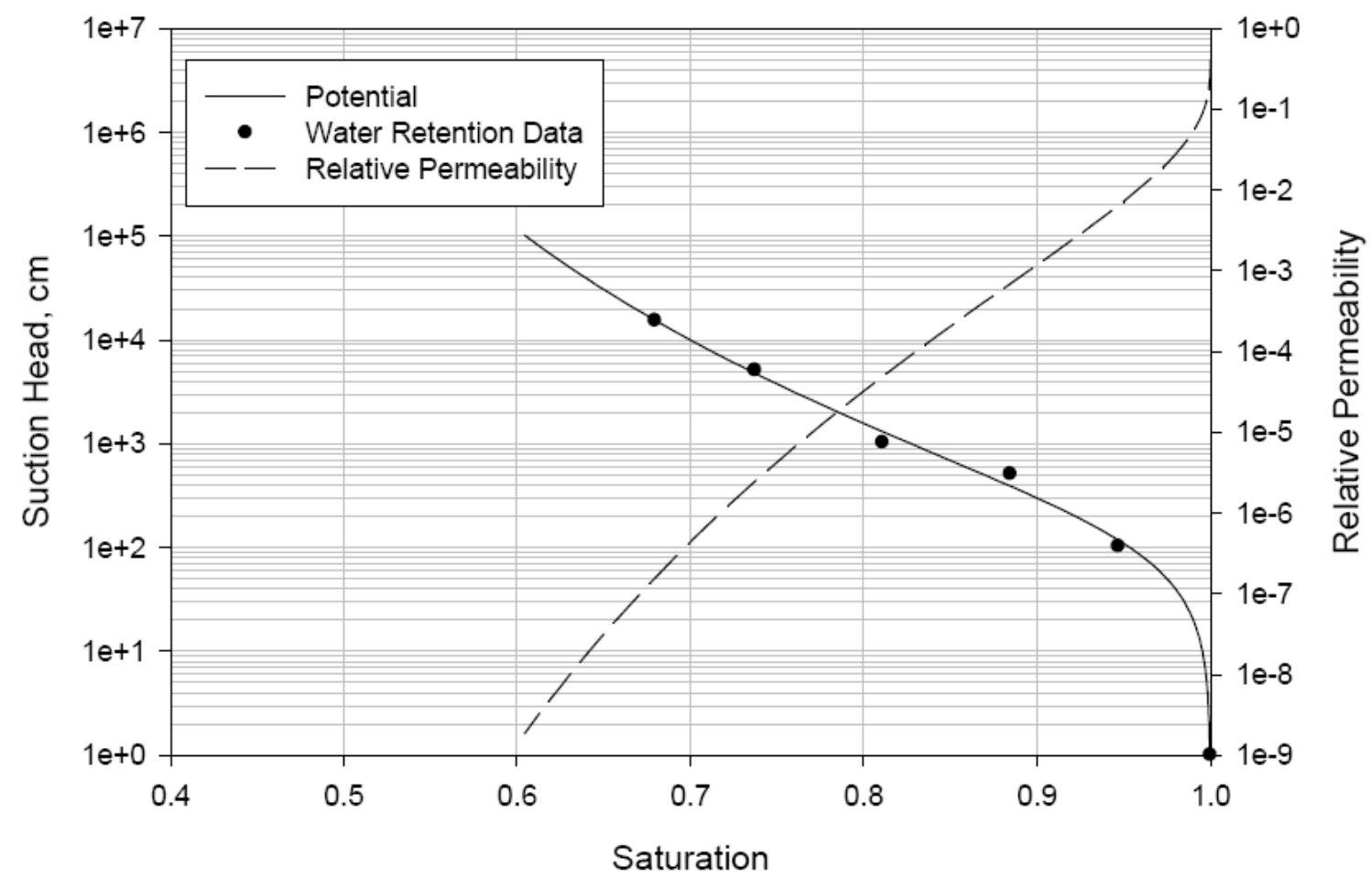

Figure B-2. Characteristic curves for Type I/II Ternary Blend 2 Reducing Grout [5]. 


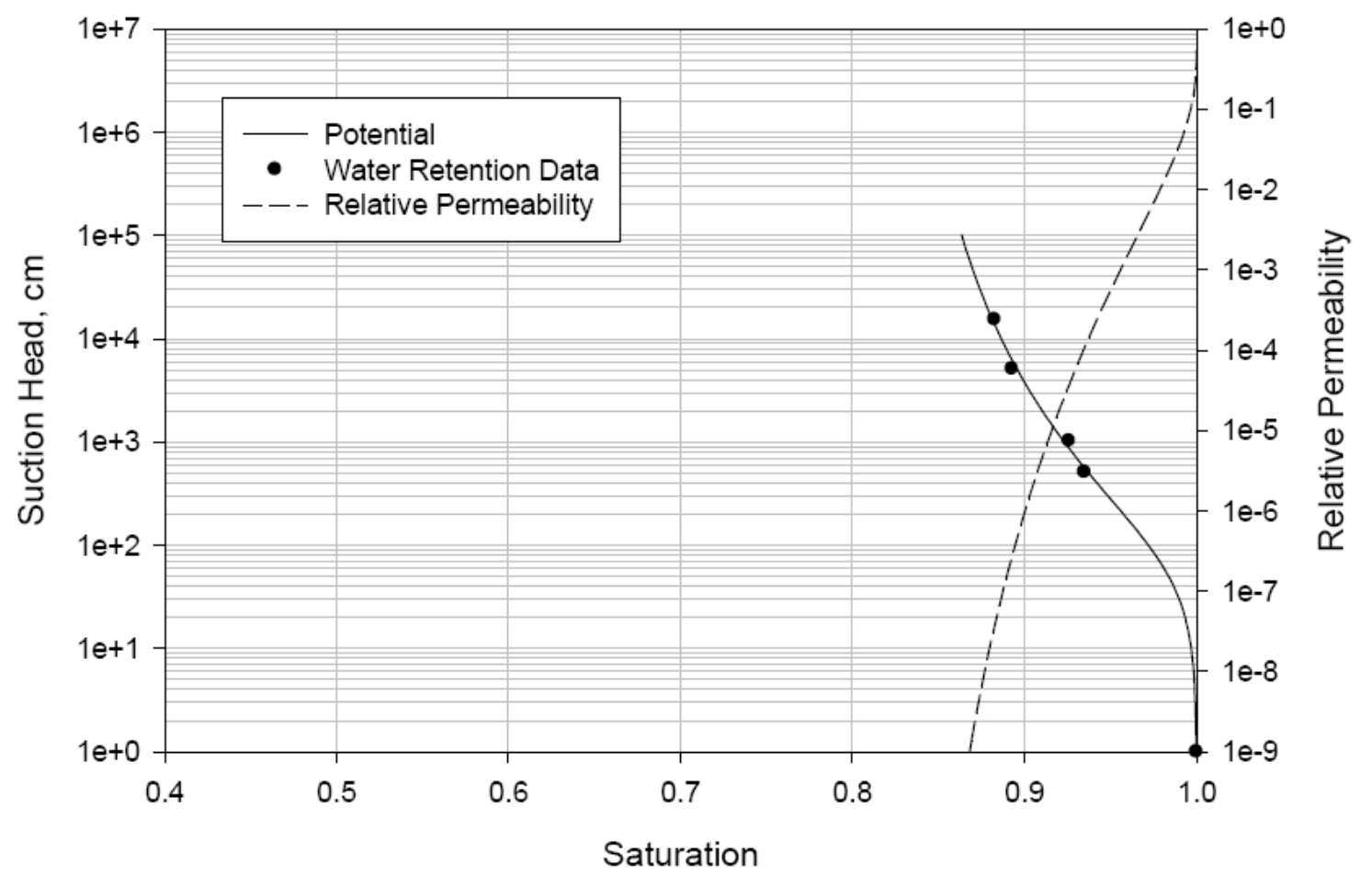

Figure B-3. Characteristic curves for Type I/II Ternary Blend 3 Reducing Grout [5].

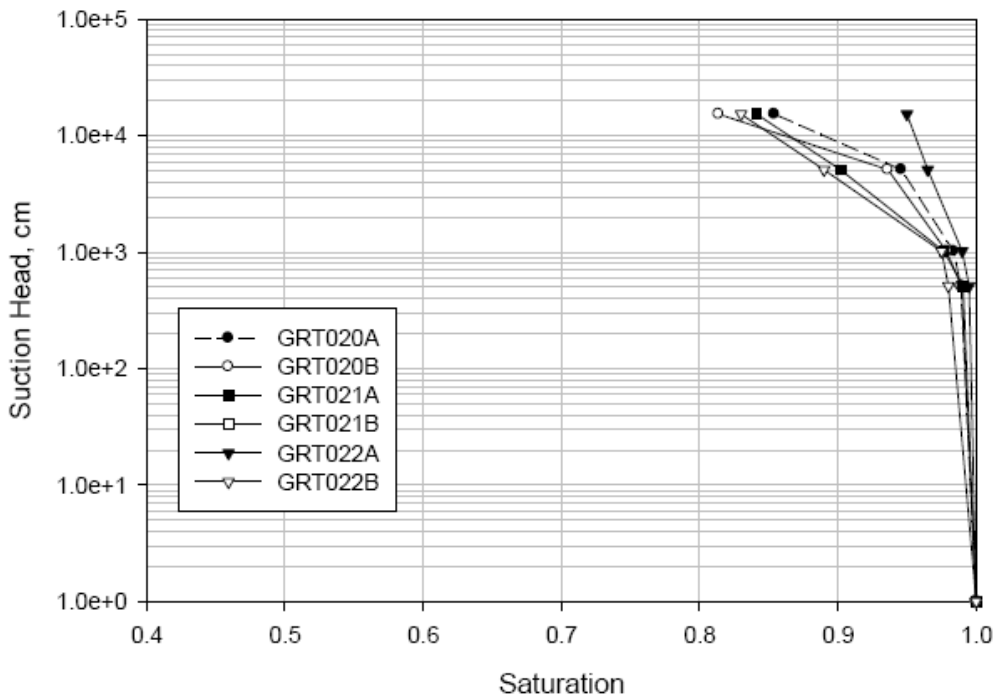

Figure B-4. Characteristic curves for Type I/II Ternary Blend 3 Reducing Grout [5]. 
6.3 ATTACHMENT C - REFERENCE CASE SALT WASTEFORM AND PHYSICAL PROPERTIES 
The reference case salt waste form is prepared from a premix of cementitious reagents and a lowlevel radioactive solution containing dissolved sodium salts. The formulation for the premix is provided in Table 3. The formulation for a typical DOE salt waste solution stabilized with the reference premix is provided in Table 4.

Table C-1. Reference Case Blended Premix Reagents for DOE Salt Waste Forms [3].

\begin{tabular}{|l|c|}
\hline \multicolumn{1}{|c|}{ Ingredient } & Wt. \% \\
\hline Type I/II Cement (ASTM C 150) & 10 \\
\hline $\begin{array}{l}\text { Grade 100 Blast Furnace Slag (ASTM C } \\
\text { 989) }\end{array}$ & 45 \\
\hline Type F Fly Ash (ASTM C 618) & 45 \\
\hline
\end{tabular}

Table C-2. Reference Case Non Radioactive Salt Waste Solution [3].

\begin{tabular}{|c|c|c|}
\hline Ingredient & $\begin{array}{c}\text { Molarity } \\
\text { (Moles/Liter) }\end{array}$ & $\begin{array}{c}\text { Mass } \\
\left(\mathrm{g} / \text { Liter } \mathrm{H}_{2} \mathrm{O}\right) \\
\end{array}$ \\
\hline $\begin{array}{l}\text { Sodium Hydroxide, } \mathrm{NaOH} \\
\text { ( } 50 \% \text { by weight solution) }\end{array}$ & 2.866 & 229.28 \\
\hline Sodium Nitrate, $\mathrm{NaNO}_{3}$ & 1.973 & 167.66 \\
\hline Sodium Nitrite, $\mathrm{NaNO}_{2}$ & 0.485 & 33.43 \\
\hline Sodium Carbonate, $\mathrm{Na}_{2} \mathrm{CO}_{3}$ & 0.118 & 12.46 \\
\hline $\begin{array}{l}\text { Aluminum Nitrate Nona-hydrate, } \\
\mathrm{Al}\left(\mathrm{NO}_{3}\right)_{3} \cdot 9 \mathrm{H}_{2} \mathrm{O}\end{array}$ & 0.114 & 42.90 \\
\hline Sodium Sulfate, $\mathrm{NA}_{2} \mathrm{SO}_{4}$ & 0.055 & 7.84 \\
\hline Sodium Phosphate $\mathrm{Na}_{3} \mathrm{PO}_{4} \cdot 12 \mathrm{H}_{2} \mathrm{O}$ & 0.007 & 2.76 \\
\hline Density $(\mathrm{g} / \mathrm{ml})$ & \multicolumn{2}{|c|}{1.248} \\
\hline Dynamic Viscosity (cP) & \multicolumn{2}{|c|}{2.78} \\
\hline Wt.\% Water & \multicolumn{2}{|c|}{71.12} \\
\hline Wt. \% Solids & \multicolumn{2}{|c|}{28.88} \\
\hline $\begin{array}{l}\text { Wt. \% Salt in Wet Waste Form with a } \\
\text { Water to Premix Ratio of } 0.60\end{array}$ & \multicolumn{2}{|c|}{13.0} \\
\hline
\end{tabular}


Table C-3. Physical and Hydraulic Properties for Reference Case Salt Waste Form [3].

\begin{tabular}{|c|c|c|}
\hline Property & $\begin{array}{c}\text { Cement-Based } \\
\text { Salt Waste Form } \\
{[3]} \\
\end{array}$ & \\
\hline \multicolumn{3}{|l|}{ Compressive Strength (psi) } \\
\hline 28 Days & $\begin{array}{c}1,213 \\
\text { Range } \\
1,200 \text { to } 1,230\end{array}$ & \\
\hline 90 Days & $\begin{array}{c}1,467 \\
\text { Range } \\
1,450 \text { to } 1,480\end{array}$ & \\
\hline $\begin{array}{l}\text { Saturated Hydraulic } \\
\text { Conductivity }(\mathrm{cm} / \mathrm{s}) \\
\text { Samples Cured } 28 \text { Days } \\
\text { (log average) }\end{array}$ & $\begin{array}{c}6.0 \mathrm{E}-09 \\
(1.5 \mathrm{E}-09)\end{array}$ & \\
\hline \multicolumn{3}{|l|}{$\begin{array}{l}\text { Intrinsic Permeability (Darcy) } \\
\text { Based on Properties of Tap } \\
\text { Water (log average) }\end{array}$} \\
\hline $\begin{array}{l}\text { Dry Bulk Density }\left(\mathrm{g} / \mathrm{cm}^{3}\right) \\
28 \text { Days } \\
\text { (arithmetic average) }\end{array}$ & 1.01 & \\
\hline $\begin{array}{l}\text { Particle Density }\left(\mathrm{g} / \mathrm{cm}^{3}\right) \\
28 \text { Days } \\
\text { (arithmetic average) }\end{array}$ & 2.42 & \\
\hline $\begin{array}{l}\text { Porosity (volume fraction) } \\
28 \text { Days } \\
\text { (arithmetic average) }\end{array}$ & 0.58 & \\
\hline $\begin{array}{l}\text { Moisture Retention Curves } \\
\text { Over Pressure Range } 102 \text { to } \\
15,296 \mathrm{~cm} \mathrm{H}_{2} \mathrm{O} \text { (0.1 to } 15 \text { bars) }\end{array}$ & $\begin{array}{l}\text { Figure C-2 } \\
\text { Figure C-3 }\end{array}$ & \\
\hline Characteristic Curves & Figure $\mathrm{C}-1$ & \\
\hline \multicolumn{3}{|l|}{$\begin{array}{l}\text { Van Genuchten Transport } \\
\text { Parameters }\end{array}$} \\
\hline$\theta_{\mathrm{s}}\left(\mathrm{cm}^{3} / \mathrm{cm}^{-3}\right)$ & 0.580 & \\
\hline$\theta_{\mathrm{r}}\left(\mathrm{cm}^{3} / \mathrm{cm}^{-3}\right)$ & 0.572 & \\
\hline$\alpha(1 / \mathrm{cm})$ & 0.1550 & \\
\hline $\mathrm{n}$ & 1.30 & \\
\hline $\mathrm{m}$ & 0.2308 & \\
\hline
\end{tabular}


Reference Cases for Use in the Cementitious Barriers Partnership Project

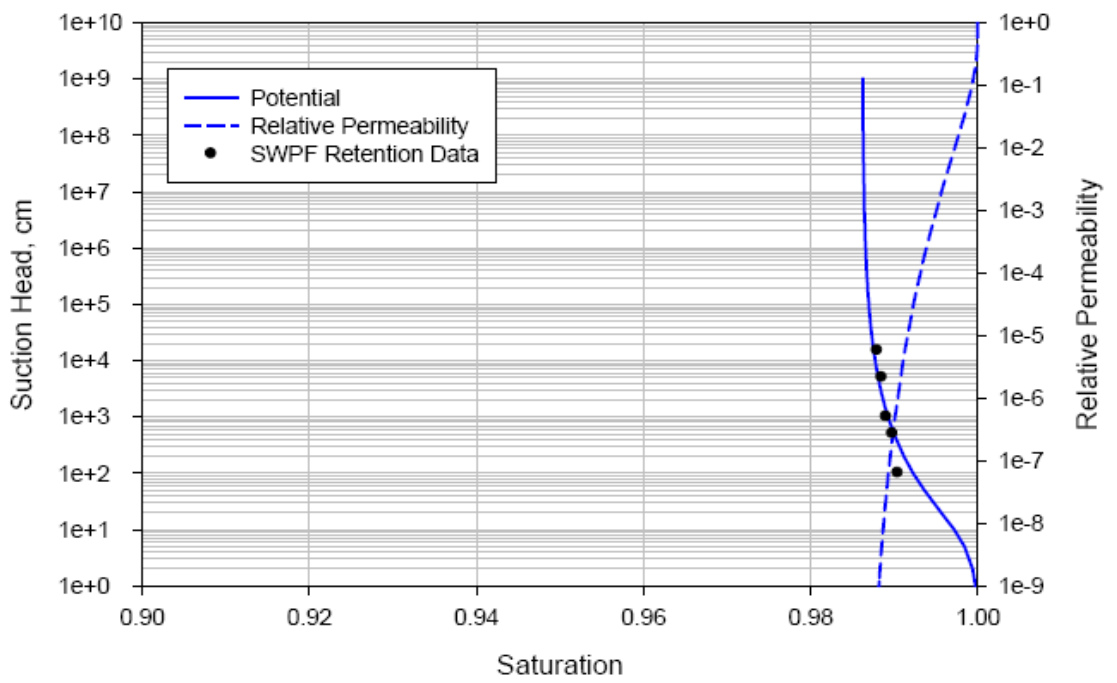

Figure C-1. Characteristic Curves for the SWPF Saltstone (using 28 and 90 day retention data). 


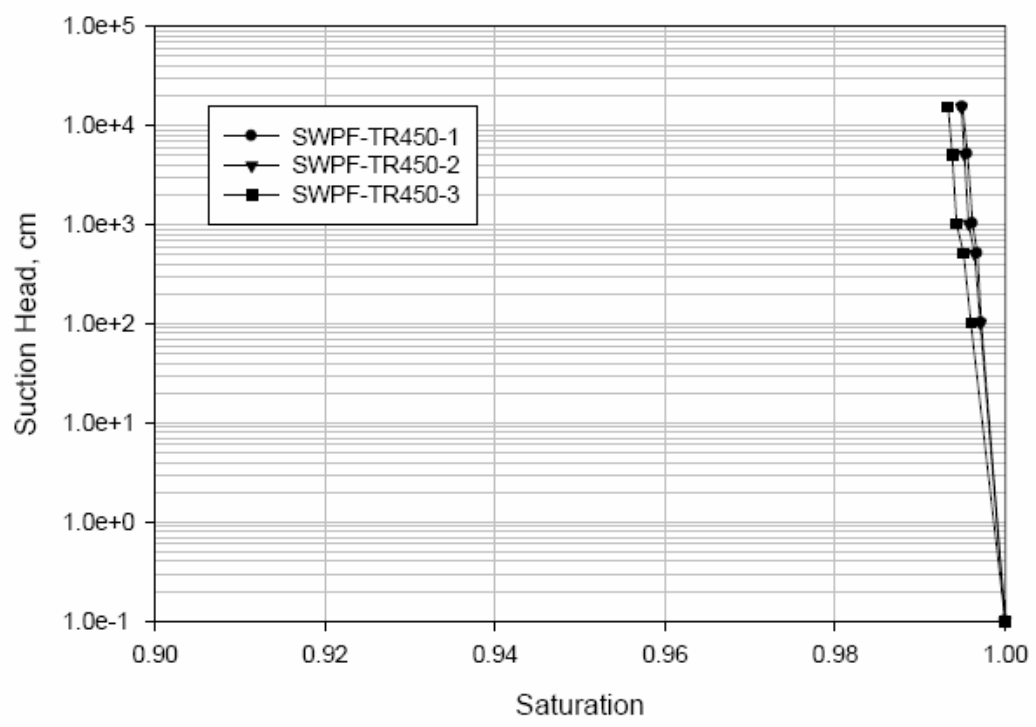

Figure C-2. Moisture retention curves for the 28 day SWPF saltstone samples.

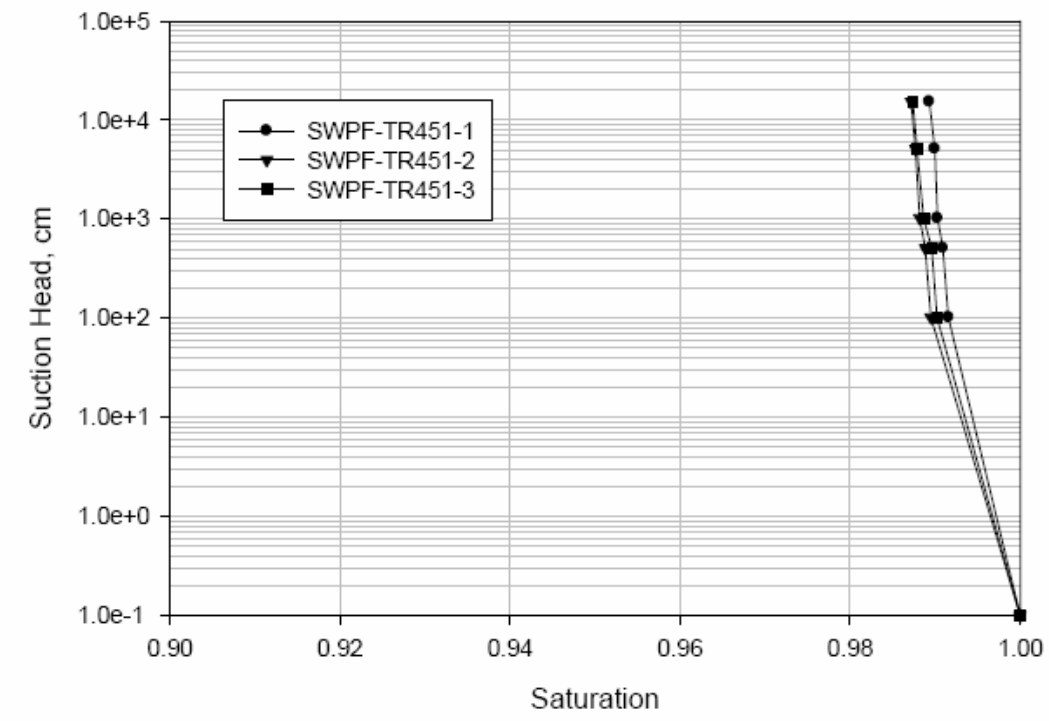

Figure C-3. Moisture retention curves for the 90 day SWPF saltstone samples. 
6.4 ATTACHMENT D - CONTAMINANT $K_{d}$ DATA FOR REFERENCE CASE ORDINARY (OXIDIZED) PORTLAND CEMENTITIOUS MATERIALS 
Table D-1. $K_{d}$ values for selected radionuclides for new and aged ordinary portland cement (oxidized) concrete used in the SRS PAs [8].

\begin{tabular}{|c|c|c|c|}
\hline Contaminant & $\begin{array}{l}\text { Stage } 1 \text { New Concrete } \\
\text { (pore solution pH } \\
\sim 12.4 \text { in equilibrium } \\
\text { with } \mathrm{Ca}(\mathrm{OH})_{2} \text { ) }\end{array}$ & $\begin{array}{c}\text { Stage } 2 \text { Partially Aged } \\
\text { Concrete } \\
\text { (pore solution pH } \sim 10.5 \\
\text { in equilibrium with } \\
\text { calcium silicate, } \\
\text { aluminate hydrates) }\end{array}$ & $\begin{array}{c}\text { Stage } 3 \text { Aged Concrete } \\
\text { (pore solution in } \\
\text { equilibrium with } \\
\mathrm{CaCO}_{3} \text { ) }\end{array}$ \\
\hline \multicolumn{4}{|c|}{ 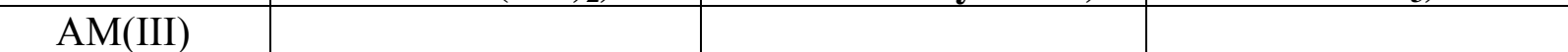 } \\
\hline \multicolumn{4}{|l|}{$\mathrm{Cd}(\mathrm{II})$} \\
\hline \multicolumn{4}{|l|}{$\mathrm{Ce}(\mathrm{III})$} \\
\hline $\mathrm{Co}(\mathrm{II})$ & 1000 & 1000 & 500 \\
\hline $\mathrm{Cs}(\mathrm{I})$ & 2 & 4 & 2 \\
\hline \multicolumn{4}{|l|}{$\mathrm{Hg}(\mathrm{I})$} \\
\hline $\mathrm{I}(\mathrm{I})$ & 8 & 20 & 0 \\
\hline \multicolumn{4}{|l|}{$\mathrm{Np}(\mathrm{V})$} \\
\hline \multicolumn{4}{|l|}{$\mathrm{Pa}(\mathrm{V})$} \\
\hline $\mathrm{Pu}(\mathrm{IV} / \mathrm{V})$ & 5000 & 5000 & 500 \\
\hline $\mathrm{Sn}(\mathrm{IV})$ & 4000 & 4000 & 2000 \\
\hline $\mathrm{Sr}(\mathrm{II})$ & 1 & 1 & 0.8 \\
\hline $\mathrm{Tc}(\mathrm{VII})$ & 0 & 0 & 0 \\
\hline $\mathrm{U}(\mathrm{VI})$ & 1000 & 1000 & 70 \\
\hline \multicolumn{4}{|l|}{$\mathrm{Y}(\mathrm{III})$} \\
\hline & & & \\
\hline & & & \\
\hline & & & \\
\hline
\end{tabular}


Table $D-2 . K_{d}$ values for selected radionuclides for new and aged ordinary portland cement(oxidizing) concrete used in the SRS PAs [9].

\begin{tabular}{|c|c|c|c|c|c|c|c|}
\hline \multirow[t]{2}{*}{$\begin{array}{l}\text { Radio- } \\
\text { nuclide }\end{array}$} & \multicolumn{2}{|c|}{$\begin{array}{l}\text { Young Cement } \\
1^{\text {st }} \text { Stage } \\
(\mathrm{pH} \sim 12.5)\end{array}$} & \multicolumn{2}{|c|}{$\begin{array}{l}\text { Moderately-aged } \\
\text { Cement, } 2^{\text {nd }} \text { Stage } \\
(\text { pH } \sim 10.5)\end{array}$} & \multicolumn{2}{|c|}{$\begin{array}{l}\text { Aged Cement }^{(\mathrm{b})} \\
3^{\text {rd }} \text { Stage } \\
(\mathrm{pH} \sim 5.5)\end{array}$} & \multirow[b]{2}{*}{ Comments/References $^{(a)}$} \\
\hline & $\begin{array}{c}\text { Conser- } \\
\text { vative }\end{array}$ & "Best" & $\begin{array}{c}\text { Conser- } \\
\text { vative }\end{array}$ & "Best" & $\begin{array}{l}\text { Conser } \\
\text {-vative }\end{array}$ & "Best" & \\
\hline & & & & & & & $\begin{array}{l}\text { cement is highly reversible when } \mathrm{Cl} \text { is added to aqueous phase, suggesting it } \\
\text { adsorbed and was not precipitated (3). Increasing pH, decreased I sorption } \\
\text { (3; therefore Stage } 3 \mathrm{~K} d \text { values will be slightly greater than other stages). } \\
\text { Iodide sorption on } \mathrm{CSH} \text { varies with its } \mathrm{C} / \mathrm{S} \text { ratio, increasing towards high } \mathrm{C} / \mathrm{S} \\
\text { ratios (3). Decreased } K d \text { values in "Young Concrete" because of high } \\
\text { concentration of aqueous salts. In } 1^{\text {st }} \text { Stage } K d \text { values were decreased because } \\
\text { high ionic strength likely resulted in anion exchange (desorption). }\end{array}$ \\
\hline$\underset{C^{(c)}}{\text { Inorganic }}$ & 14 & 20 & 7 & 10 & 0 & 0 & $\begin{array}{l}{ }^{14} \mathrm{C} \text { chemistry is very complicated and is not well characterized by the } \mathrm{Kd} \\
\text { construct. It is influenced by carbon dioxide gas/water/solid phase } \\
\text { equilibrium, isotopic exchange, adsorption, precipitation, and coprecipitation. } \\
\text { To be conservative the role of gas phase and isotopic exchange (two very } \\
\text { important processes for removing }{ }^{14} \mathrm{C} \text { from groundwater) will not be } \\
\text { considered. Inorganic } \mathrm{C} \text { exists as an anion, } \mathrm{CO}_{3}{ }^{2-}(I) \text {. Subsurface } \mathrm{C} \\
\text { chemistry in a cementitious environment is discussed by Dayal }(7,8) \text { and how } \\
\text { it has been applied to the SRS by Kaplan }(9) \text {. }\end{array}$ \\
\hline $\begin{array}{l}\mathrm{Ac}, \mathrm{Am} \\
\mathrm{Bk}, \mathrm{Cf} \\
\mathrm{Cm}, \mathrm{Eu} \\
\mathrm{Gd}, \mathrm{Sm}\end{array}$ & 2500 & 5000 & 2500 & 5000 & 360 & 500 & $\begin{array}{l}\text { Trivalent cation } K d \text { values for concrete exceed those for sediments (3). Am } \\
K d>10,000 \mathrm{~mL} / \mathrm{g}(10) \text {. Am } K d \text { value was } 12,000 \mathrm{~mL} / \mathrm{g} \text { based on diffusion } \\
\text { tests in cement }(11) \text {. Am } K d \text { values ranged from } 2,500 \text { to } 35,000 \mathrm{~mL} / \mathrm{g} \text { for } 7 \\
\text { fresh concrete blends }(1,6) \text {. Am } K d \text { for } 65 \text {-yr old concrete sample }=10,000 \\
\mathrm{~mL} / \mathrm{g}(1,6) \text {. Fresh cement Am } K d=2000 \text { for } 24-\mathrm{h} \text { contact time }(12) \text {. Eu } K d= \\
2,400 \mathrm{~mL} / \mathrm{g} \text { for } 24-\mathrm{h} \text { contact time }(12) \text {. Very large } K d \text { values may reflect } \\
\text { precipitation reaction that occurred during the adsorption measurements. }\end{array}$ \\
\hline $\mathrm{Co}, \mathrm{Ni}$ & 500 & 1000 & 500 & 1000 & 360 & 500 & $\begin{array}{l}\text { Three studies were found that included adsorption data for Ni onto } \\
\text { cement/concrete. Hietanen et al (15) reported } K d \text { values that ranged from } 500 \\
\text { to } 3000 \mathrm{~mL} / \mathrm{g} \text {, Kato and Yanase }(12) \text { reported a Ni } K d \text { value of } 1500 \mathrm{~mL} / \mathrm{g} \text {, } \\
\text { and Pilkington and Stone }(16) \text { reported } K d \text { values that ranged from } 500 \text { to } \\
3000 \mathrm{~mL} / \mathrm{g} \text {. }\end{array}$ \\
\hline $\mathrm{Ra}, \mathrm{Ba}$ & 70 & 100 & 70 & 100 & 50 & 70 & $\begin{array}{l}\text { Bayliss et al. (11) and Berry et al. (13) measured Ra } K d \text { values onto ordinary } \\
\text { Portland cement and as a function of Ra concentration. They reported } K d \text { that } \\
\text { ranged from } 50 \text { to } 530 \mathrm{~mL} / \mathrm{g} \text {. }\end{array}$ \\
\hline $\mathrm{Sr}$ & 0.2 & 1 & 0.5 & 1 & 0.2 & 0.8 & $\begin{array}{l}\text { Jakubick et al. (14) reported } \mathrm{Sr} K d \text { values of } 0.8 \text { to } 1.6 \mathrm{~mL} / \mathrm{g} \text { for high density } \\
\text { and normal density concretes, and } 1.3 \text { to } 3 \mathrm{~mL} / \mathrm{g} \text { for the same concretes, but } \\
\text { in lower ionic strength solutions. Ewart et al. (14) reported } K d \text { values } \\
\text { between } 1 \text { and } 4 \mathrm{~mL} / \mathrm{g} \text {. Kato and Yanase reported a Sr } K d \text { value of } 56 \mathrm{~mL} / \mathrm{g} \\
\text { for an experiment involving } 24 \mathrm{~h} \text { contact time, dried cement powder, } \mathrm{pH} 11\end{array}$ \\
\hline
\end{tabular}


Reference Cases for Use in the Cementitious Barriers Partnership Project

\begin{tabular}{|c|c|c|c|c|c|c|c|}
\hline \multirow[t]{2}{*}{$\begin{array}{l}\text { Radio- } \\
\text { nuclide }\end{array}$} & \multicolumn{2}{|c|}{$\begin{array}{l}\text { Young Cement } \\
1^{\text {st }} \text { Stage } \\
(\mathrm{pH} \sim 12.5)\end{array}$} & \multicolumn{2}{|c|}{$\begin{array}{l}\text { Moderately-aged } \\
\text { Cement, } 2^{\text {nd }} \text { Stage } \\
\quad(\mathrm{pH} \sim 10.5)\end{array}$} & \multicolumn{2}{|c|}{$\begin{array}{c}\text { Aged Cement }{ }^{(b)} \\
3^{\text {rd }} \text { Stage } \\
(\mathrm{pH} \sim 5.5)\end{array}$} & \multirow[b]{2}{*}{ Comments/References $^{(a)}$} \\
\hline & $\begin{array}{l}\text { Conser- } \\
\text { vative }\end{array}$ & "Best" & $\begin{array}{l}\text { Conser- } \\
\text { vative }\end{array}$ & "Best" & $\begin{array}{l}\text { Conser } \\
\text {-vative }\end{array}$ & "Best" & \\
\hline & & & & & & & $\begin{array}{l}\text { cement equilibrated water. We elected to disregard this value because it is an } \\
\text { order-of-magnitude greater than those reported by other researchers and the } \\
\text { nature of the solid phase was not clearly described by the author. In } 1^{\text {st }} \text { Stage } \\
K d \text { values were decreased because high ionic strength likely results in } \\
\text { competitive exchange (desorption). }\end{array}$ \\
\hline $\mathrm{Sn}$ & 2000 & 4000 & 2000 & 4000 & 1000 & 2000 & $\begin{array}{l}\text { Sn exists in cementitious environments in the }+4 \text { state }(17) \text { and as such } \\
\text { readily hydrolyses. Using sulfate resistant Portand cement, Sn } K d \text { values } \\
\text { were }>30,000 \mathrm{~mL} / \mathrm{g} \text {; this likely reflected some precipitation }(17) \text {. }\end{array}$ \\
\hline $\mathrm{Cs}, \mathrm{Fr}$ & 1 & 2 & 2 & 4 & 1 & 2 & $\begin{array}{l}\text { Cs } K d \text { values in hardened HTS cement discs, } \mathrm{pH} 13.3 \text { were close to } 3 \mathrm{~mL} / \mathrm{g} \\
(15) \text {. Wieland and Van Loon (17) reviewed Cs } K d \text { values onto various } \\
\text { cementitious materials and they had a very narrow range: from } 0.2 \text { to } 5.0 \\
\mathrm{~mL} / \mathrm{g} \text {. In } 1^{\text {st }} \text { Stage } K d \text { values were decreased because high ionic strength } \\
\text { likely results in competitive exchange (desorption). This has been shown } \\
\text { experimentally (17). }\end{array}$ \\
\hline $\mathrm{Nb}$ & 500 & 1000 & 500 & 1000 & 360 & 500 & $\begin{array}{l}\text { Krupka and Serne ( }(18) \text { review } \mathrm{Nb} K d \text { values and concluded that there was a } \\
\text { great deal of variability related in } \mathrm{Nb} \text { sorption data to cementitious materials. } \\
\text { They reported } K d \text { ranges of } 11 \text { to } 69,000 \mathrm{~mL} / \mathrm{g} \text { (from studies that had } \\
\text { problems with the blanks, i.e., the blanks indicated Nb sorbed to the } \\
\text { glassware). We defer to their best values }(1000 \mathrm{~mL} / \mathrm{g} \text { ) and add conservatism } \\
\text { to these values. }\end{array}$ \\
\hline $\mathrm{Np}, \mathrm{Pa}$ & 1000 & 2000 & 1000 & 2000 & 140 & 200 & $\begin{array}{l}\text { These radionuclides are assumed to exist in the }+5 \text { oxidation state. Np } \\
\text { sorption test to } 7 \text { different } 65 \text {-yr old cements using cement pore water reached } \\
\text { steady state after } 30 \text { days, } K d \text { values ranged from } 1500 \text { to } 9500 \mathrm{~mL} / \mathrm{g}(1,6) \text {. } \\
\text { As is the case with all large } K d \text { values, these values may reflect some } \\
\text { precipitation occurring during the adsorption measurement. }\end{array}$ \\
\hline $\mathrm{Se}, \mathrm{Te}$ & 100 & 300 & 210 & 300 & 110 & 150 & $\begin{array}{l}\text { Twenty-seven cementitious formulations (varying water } / \text { solid, silica fume \%, } \\
\text { and clay concentration) were used to measure selenate }\left(\mathrm{SeO}_{3}{ }^{2-}\right) K d \text { values } \\
\text { from an alkaline solution (Johnson et al. } 2000) . K d \text { values ranged from } 250 \\
\text { to } 930 \mathrm{~mL} / \mathrm{g} \text {. Sorption was irreversible. At high selenate }\left(\mathrm{SeO}_{4}{ }^{2-}\right) \\
\text { concentrations, sorption to ettringite, monosulfate, calcium-silicate-hydrate } \\
\text { (all mineral constituents of concrete) resulted in selenate substitutes for } \\
\text { sulfate (23). Selenite } K d \text { values measured in sulfate resistant Portland cement } \\
\text { ranged from } 30 \text { to } 100 \mathrm{~mL} / \mathrm{g} \text { (Wieland and Van Loon } 2003 \text { ). It is not clear } \\
\text { why these latter } K d \text { values were so much lower than those reported by } \\
\text { Johnson et al (2000). This variability in results requires that conservative }\end{array}$ \\
\hline
\end{tabular}


Reference Cases for Use in the Cementitious Barriers Partnership Project

\begin{tabular}{|c|c|c|c|c|c|c|c|}
\hline \multirow[t]{2}{*}{$\begin{array}{l}\text { Radio- } \\
\text { nuclide }\end{array}$} & \multicolumn{2}{|c|}{$\begin{array}{c}\text { Young Cement } \\
1^{\text {st }} \text { Stage } \\
(\mathrm{pH} \sim 12.5) \\
\end{array}$} & \multicolumn{2}{|c|}{$\begin{array}{c}\text { Moderately-aged } \\
\text { Cement, } 2^{\text {vd }} \text { Stage } \\
\text { (pH } \sim 10.5)\end{array}$} & \multicolumn{2}{|c|}{$\begin{array}{c}\text { Aged Cement } \\
3^{\text {rd }} \text { Stage } \\
(\mathrm{pH} \sim 5.5)\end{array}$} & \multirow[b]{2}{*}{ Comments/References $^{(a)}$} \\
\hline & $\begin{array}{l}\text { Conser- } \\
\text { vative }\end{array}$ & "Best" & $\begin{array}{l}\text { Conser- } \\
\text { vative }\end{array}$ & "Best" & $\begin{array}{l}\text { Conser } \\
\text {-vative }\end{array}$ & "Best" & \\
\hline & & & & & & & values in table be lowered. \\
\hline $\mathrm{Pb}, \mathrm{Po}$ & 250 & 500 & 250 & 500 & 180 & 250 & $\begin{array}{l}\text { Soft divalent cations: Bayliss et al. (1988) conducted a series of sorption } \\
\text { experiments with } \mathrm{Pb} \text { and crushed sulfate resisting Portland cement and } \\
\text { ordinary Portland cement/blast furnace slag pastes with an Eh of }+50 \text { to }-500 \\
\mathrm{mV} \text {. The main findings were that sorption was concentration and cement } \\
\text { composition dependent. Data strongly suggested solubility controls on } \mathrm{Pb} \\
\text { aqueous concentrations. "Best" estimates taken from }(19) \text {. }\end{array}$ \\
\hline $\begin{array}{c}\mathrm{Pu}(\mathrm{II} / \mathrm{IV}), \\
\mathrm{Pu}(\mathrm{V} / \mathrm{VI}), \\
\mathrm{Pu} \text { (combo) } \\
\mathrm{Th}, \mathrm{Zr}\end{array}$ & 1000 & 5000 & 1000 & 5000 & 250 & 500 & $\begin{array}{l}\text { Concrete containing reducing agents (blast furnace slag, BFS) did not have } \\
\text { greater Pu } K d \text { values than those that did not contain BFS. High } K d \text { values are } \\
\text { attributed more to low solubility of Pu in high pH systems, than to } \\
\text { adsorption/absorption processes. Using three } 65 \text {-yr-old crushed concrete } \\
\text { samples and seven fresh concrete samples, Th- } K d \text { values were } 2,500 \text { to } 5,500 \\
\mathrm{~mL} / \mathrm{g}(1, \sigma) \text {. Th- } K d \text { values were consistently less than Am } K d \text { values, greater } \\
\text { than } \mathrm{U}-K d \text { values, and very similar to } \mathrm{Np} \text { and } \mathrm{Pu} K d \text { values }(1, \sigma) \text {. Pu- } K d \\
\text { values ranged from } 1,000 \text { to } 12,000 \mathrm{~mL} / \mathrm{g}(1, \sigma) \text {. Using a sulfate resistant } \\
\text { Portland cement, Th } K d \text { values were measured to be } 100,000 \mathrm{~mL} / \mathrm{g}(17) \text {. }\end{array}$ \\
\hline $\mathrm{U}$ & 500 & 1000 & 500 & 1000 & 50 & 70 & $\begin{array}{l}\text { U(VI)- } K d \text { values for } 7 \text { types of cement were } 350 \text { to } 13,000 \mathrm{~mL} / \mathrm{g} ; \text { median }= \\
1400 \mathrm{~mL} / \mathrm{g}(1,6) \text {. }\end{array}$ \\
\hline \multicolumn{8}{|c|}{ 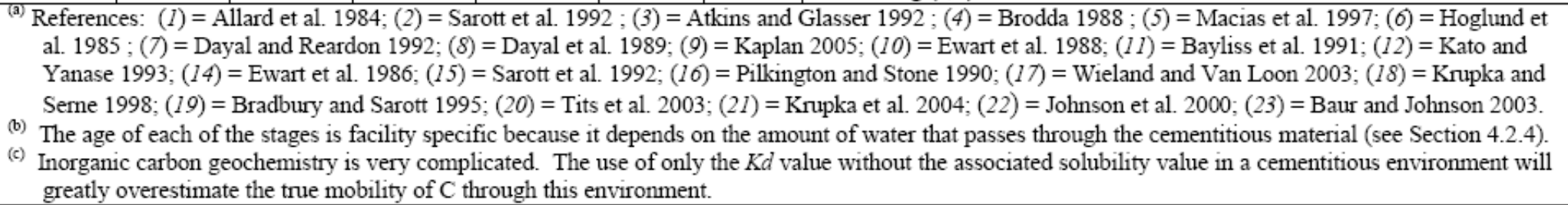 } \\
\hline
\end{tabular}


6.5 ATTACHMENT E - CONTAMINANT $K_{d}$ DATA FOR REFERENCE CASE CHEMICALLY REDUCED CEMENTITIOUS MATERIALS 
Table E-1. Summary of $K_{d}$ values for selected radionuclides for new and aged chemically reduced concrete used in the SRS PAs [10].

\begin{tabular}{|c|c|c|c|}
\hline Contaminant & $\begin{array}{l}\text { Stage } 1 \text { New Concrete } \\
\text { (pore solution pH } \\
\sim 12.4 \text { in equilibrium } \\
\text { with } \mathrm{Ca}(\mathrm{OH})_{2} \text { ) }\end{array}$ & $\begin{array}{c}\text { Stage } 2 \text { Partially Aged } \\
\text { Concrete } \\
\text { (pore solution pH } \sim 10.5 \\
\text { in equilibrium with } \\
\text { calcium silicate, } \\
\text { aluminate hydrates }\end{array}$ & $\begin{array}{c}\text { Stage } 3 \text { Aged Concrete } \\
\text { (pore solution in } \\
\text { equilibrium with } \\
\mathrm{CaCO}_{3} \text { ) }\end{array}$ \\
\hline $\mathrm{Sn}$ & 5,000 & 5,000 & 2,000 \\
\hline $\mathrm{Am}$ & 5,000 & 5,000 & 1,000 \\
\hline $\mathrm{Ce}$ & 5,000 & 5,000 & 1,000 \\
\hline $\mathrm{Y}$ & 5,000 & 5,000 & 1,000 \\
\hline $\mathrm{Cd}$ & 5,000 & 5,000 & 1,000 \\
\hline $\mathrm{Co}$ & 5,000 & 5,000 & 1,000 \\
\hline $\mathrm{Hg}$ & 1,000 & 1,000 & 300 \\
\hline $\mathrm{Sr}$ & $0.5-3.0$ & $0.5-3.0$ & 20 \\
\hline $\mathrm{U}$ & 2,500 & 2,500 & 2,500 \\
\hline $\mathrm{Cs}$ & $0-2$ & $0-2$ & 10 \\
\hline $\mathrm{Np}(\mathrm{V})$ & $\begin{array}{c}2,000 \\
4,000 \text { recommended }\end{array}$ & $\begin{array}{c}3,000 \\
4,000 \text { recommended }\end{array}$ & $\begin{array}{c}200-300 \\
3,000 \text { recommended }\end{array}$ \\
\hline $\mathrm{Pa}(\mathrm{V})$ & 5,000 & 5,000 & 500 \\
\hline $\mathrm{Pu}$ & $\begin{array}{c}5,000 \\
10,000 \text { recommended }\end{array}$ & $\begin{array}{c}5,000 \\
10,000 \text { recommended }\end{array}$ & $\begin{array}{c}500 \\
10,000 \text { recommended }\end{array}$ \\
\hline I & $5-9$ & $5-9$ & 0 \\
\hline $\mathrm{Tc}(\mathrm{VII})$ & 5,000 & 5,000 & 5,000 \\
\hline $\mathrm{Se}$ & 300 & 300 & 300 \\
\hline & & & \\
\hline & & & \\
\hline
\end{tabular}


Table E-2. $K_{d}$ values for selected radionuclides for new and aged chemically reduced concrete used in the SRS PAs [9].

Table 14. Distribution coefficients ( $K d$ values, $\mathrm{mL} / \mathrm{g}$ ): Reducing Cementitious Solids

\begin{tabular}{|c|c|c|c|c|c|c|c|}
\hline \multirow[t]{2}{*}{$\begin{array}{l}\text { Radio- } \\
\text { nuclide }\end{array}$} & \multicolumn{2}{|c|}{$\begin{array}{c}\text { Young Cement } \\
(\mathrm{pH} \sim 12.5)\end{array}$} & \multicolumn{2}{|c|}{$\begin{array}{c}\text { Moderately-aged } \\
\text { Cement (pH 10.5) } \\
\end{array}$} & \multicolumn{2}{|c|}{$\begin{array}{l}\text { Aged Cement } \\
(\mathrm{pH} \sim \mathbf{5 . 5})\end{array}$} & \multirow[b]{2}{*}{ Comments/References $^{(a)}$} \\
\hline & $\begin{array}{c}\text { Conser- } \\
\text { vative }\end{array}$ & "Best" & $\begin{array}{l}\text { Conser- } \\
\text { vative }\end{array}$ & "Best" & $\begin{array}{c}\text { Conser- } \\
\text { vative }\end{array}$ & "Best" & \\
\hline \multicolumn{2}{|c|}{$\begin{array}{c}{ }^{3} \mathrm{H}, \mathrm{Cl}, \mathrm{Kr}, \mathrm{Rn}, \mathrm{Sr}, \\
\mathrm{Ra}, \mathrm{Zr}, \mathrm{Th}, \mathrm{Nb}, \mathrm{Sn}, \\
\mathrm{I}, \mathrm{Cs}, \mathrm{Ac}, \mathrm{Am}, \mathrm{Cf}, \\
\mathrm{Cm}, \mathrm{Eu}, \mathrm{Po}, \mathrm{Se}, \mathrm{C}, \\
\mathrm{Co}, \mathrm{Ni}, \mathrm{Pb}, \mathrm{Bk}, \mathrm{Sm}, \\
\mathrm{Fr}, \mathrm{Gd}, \mathrm{At}, \mathrm{Ar}, \mathrm{Te}, \\
\mathrm{Ba}, \mathrm{Np}, \mathrm{Pa}, \mathrm{Pu}, \mathrm{Rb}, \\
\mathrm{Pu}(\mathrm{IV}), \mathrm{Pu}(\mathrm{V}), \\
\mathrm{Pu}(\mathrm{combo})\end{array}$} & \multicolumn{5}{|c|}{$\begin{array}{c}\text { (Same values as reported in Table } 13 \text { for Oxidizing } \\
\text { Cementitious Solids) }\end{array}$} & $\begin{array}{l}\text { Concrete containing reducing agents (blast furnace slag, BFS) did not } \\
\text { have greater } \mathrm{Pu}, \mathrm{Np} \text {, or } \mathrm{Pa} K d \text { values than those that did not contain BFS } \\
(1,2,3) \text {. }\end{array}$ \\
\hline Tc, Re & 2500 & 5000 & 2500 & 5000 & 2500 & 5000 & $\begin{array}{l}\mathrm{Tc}^{\mathrm{VII}} \mathrm{O}_{4} \text {. gets reduced to } \mathrm{Tc}^{4+} \text {, which like other tetravalent cations sorbs } \\
\text { strongly to surfaces. "Best" values taken from Bradbury and Sarott } \\
\text { (1995). }\end{array}$ \\
\hline $\mathrm{U}$ & 2500 & 5000 & 2500 & 5000 & 2500 & 5000 & $\begin{array}{l}\mathrm{UO}_{2}{ }^{2+} \text { gets reduced to } \mathrm{U}^{4+} \text {, which like other tetravalent cations sorbs } \\
\text { strongly to surfaces. "Best" Values taken from Bradbury and Sarott } \\
(1995) \text {. }\end{array}$ \\
\hline
\end{tabular}




\subsection{ATTACHMENT F - CONTAMINANT SOLUBILITY DATA FOR ORDINARY PORTLAND (OXIDIZING) REFERENCE}


Table F-1. Radionuclide solubility data for ordinary portland cement (oxidized) young, moderately aged and aged concrete [9]

Table 11. Apparent solubility concentration limits ( $\mathrm{mol} / \mathrm{L}$ or $\mathrm{M}$ ) for Oxidizing Cementitious Solids

\begin{tabular}{|c|c|c|c|c|c|c|c|}
\hline \multirow[t]{2}{*}{$\begin{array}{l}\text { Radio- } \\
\text { nuclide }\end{array}$} & \multicolumn{2}{|c|}{$\begin{array}{c}\text { Young Cement } \\
1^{\text {st }} \text { Stage } \\
(\mathrm{pH} \sim 12.5)\end{array}$} & \multicolumn{2}{|c|}{$\begin{array}{c}\text { Moderately-aged } \\
\text { Cement, } 2^{\text {nd }} \text { Stage } \\
(\mathrm{pH} \sim 10.5)\end{array}$} & \multicolumn{2}{|c|}{$\begin{array}{c}\text { Aged Cement }^{(b)} \\
3^{\text {rd }} \text { Stage } \\
(\mathrm{pH} \sim 5.5)\end{array}$} & \multirow[b]{2}{*}{ Comments/References $^{(a)}$} \\
\hline & $\begin{array}{c}\text { Conser- } \\
\text { vative }\end{array}$ & "Best" & $\begin{array}{c}\text { Conser- } \\
\text { vative }\end{array}$ & "Best" & $\begin{array}{c}\text { Conser- } \\
\text { vative }\end{array}$ & "Best" & \\
\hline
\end{tabular}




\begin{tabular}{|c|c|c|c|c|c|c|c|}
\hline \multirow[t]{2}{*}{$\begin{array}{l}\text { Radio- } \\
\text { nuclide }\end{array}$} & \multicolumn{2}{|c|}{$\begin{array}{l}\text { Young Cement } \\
1^{\text {st }} \text { Stage } \\
(\mathrm{pH} \sim 12.5)\end{array}$} & \multicolumn{2}{|c|}{$\begin{array}{l}\text { Moderately-aged } \\
\text { Cement, } 2^{\text {nd }} \text { Stage } \\
\quad(\mathrm{pH} \sim 10.5)\end{array}$} & \multicolumn{2}{|c|}{$\begin{array}{l}\text { Aged Cement }^{(b)} \\
3^{\text {rd }} \text { Stage } \\
(\mathrm{pH} \sim \mathbf{5 . 5})\end{array}$} & \multirow[b]{2}{*}{ Comments/References $^{\text {(a) }}$} \\
\hline & $\begin{array}{c}\text { Conser- } \\
\text { vative }\end{array}$ & "Best" & $\begin{array}{l}\text { Conser- } \\
\text { vative }\end{array}$ & "Best" & $\begin{array}{c}\text { Conser- } \\
\text { vative }\end{array}$ & "Best" & \\
\hline $\mathrm{Co}, \mathrm{Ni}$ & $5 \times 10^{-5}$ & $10^{-1}$ & $5 \times 10^{-6}$ & $10^{-7}$ & $5 \times 10^{-5}$ & $10^{-0}$ & $\begin{array}{l}\text { Solid phase assumed to control solubility is } \mathrm{Co}(\mathrm{OH})_{2}(5,6) \text {. Experiments } \\
\text { with sulfate resistant Portland cement had } \mathrm{Co} \text { solubility values of } 5 \mathrm{e}-8 \\
\text { and } 2 \mathrm{e}-7 \mathrm{M} \text { at } \mathrm{pH} 13.3(6) \text {. The solubility of } \mathrm{Co}(\mathrm{OH})_{2} \text { was calculated to } \\
\text { be } 6.5 \mathrm{e}-5 \mathrm{M}(6) \text {. Calculated values are considered less reliable than } \\
\text { experimental values. Experiments and calculations have also been done } \\
\text { with aged cement end members under alkaline cement conditions }(2,4 \text {, } \\
7) \text {. Several experiments show solubility controls }(6,2,4,7) \text {. Solubility } \\
\text { controls of Ni are shown by }(8,9,10) \text {. Ni concentrations consistently in } \\
\text { range of } 5 \mathrm{e}-8 \text { to } 2 \mathrm{e}-7 \mathrm{M} \text { regardless of the solid/liquid ratio }(6) \text {. }\end{array}$ \\
\hline $\mathrm{Np}, \mathrm{Pa}$ & $5 \times 10^{-1}$ & $10^{-8}$ & $5 \times 10^{-7}$ & $10^{-8}$ & $5 \times 10^{-6}$ & $10^{-1}$ & $\begin{array}{l}\text { Oxidation state of radionuclides is }+5 \text {. Assume that } \mathrm{NpO}_{2}^{+} \text {and } \mathrm{PaO}_{2}{ }^{+} \text {is } \\
\text { the controlling solid. There is empirical data in Ewart et al. (2) that } \\
\text { predicts much lower concentrations than thermodynamic predictions } \\
(2,4,7) \text {. Allard et al. (1984) added } \mathrm{Np}(\mathrm{V}) \text { to a variety of cements \& } \\
\text { measured solubility after } 100 \text { days of } 4 \mathrm{e}-9 \mathrm{M} \text {. Solubility of } \mathrm{Np}(\mathrm{IV}) \text { is } \\
\sim 1 \mathrm{e}-8 \mathrm{M} \text { for } \mathrm{pH} 9.75 \text { through pH } 12.6(3) \text {. Thus, according to Allard et } \\
\text { al. (1984) and Ewart et al (1992) solubility of } \mathrm{Np} \text { is about the same in } \\
\text { concrete whether it is in }+4 \text { or }+5 \text { state. }\end{array}$ \\
\hline $\mathrm{Ra}$ & $5 \times 10^{-5}$ & $10^{-6}$ & $5 \times 10^{-3}$ & $10^{-6}$ & $5 \times 10^{-5}$ & $10^{-6}$ & $\begin{array}{l}\mathrm{RaSO}_{4} \text { is the controlling solid }(1,14) \text {. Bayliss et al. (1989) found no } \\
\text { precipitation for Ra at } \cdot 1 \mathrm{e}-7 \mathrm{M} \text { in concrete leachate. When appropriate, } \\
\text { such as in the Salstone Facility, it may be necessary to use sulfate } \\
\text { controlling solubility phases, i.e., } \mathrm{BaSO}_{4} \text { and } \mathrm{SrSO}_{4} \text {. }\end{array}$ \\
\hline $\mathrm{Sr}, \mathrm{Ba}$ & $5 \times 10^{-4}$ & $10^{-5}$ & $5 \times 10^{-4}$ & $10^{-5}$ & NA & NA & $\begin{array}{l}\mathrm{SrCO}_{3} \text { is solubility controlling phase. However, Sr may coprecipitate as } \\
(\mathrm{Ca}, \mathrm{Sr}) \mathrm{CO}_{3} \text { which has an even lower solubility value }(12) \text {. But solubility } \\
\text { controls are only important at } \mathrm{pH}<11 \text {, i.e., in the absence of } \mathrm{Ca}(\mathrm{OH})_{2} \text { and } \\
\text { high ratios of calcium-silicate-hydrate gel }(12) \text {. Therefore, } \\
\text { coprecipitation is unlikely in the paste matrix, but may occur at the } \\
\text { cement/leachate interface. For this reason Atkins and Glasser }(12) \\
\text { recommend a minimum Sr solubility of } \sim 2 \mathrm{e}-5 \mathrm{M} \text {. This solubility value is } \\
\text { likely to decrease even further if coprecipitation occurs }(13) \text {. No } \\
\text { solubility data is provided for "Aged Cement in the } 3^{\text {rd }} \text { Stage" because it } \\
\text { is believed that it will likely not precipitate in this stage. }\end{array}$ \\
\hline $\begin{array}{c}\mathrm{Pb}, \mathrm{Po}, \\
\mathrm{Pu}(\mathrm{V} / \mathrm{VI}) \\
\mathrm{Pu}(\mathrm{III} / \mathrm{IV}) \\
\mathrm{Pu}(\mathrm{combo})\end{array}$ & $5 \times 10^{-1}$ & $10^{-8}$ & $5 \times 10^{-7}$ & $10^{-8}$ & $5 \times 10^{-6}$ & $10^{-1}$ & $\begin{array}{l}\text { Assumed solubility controlling phase are hydroxide/hydrous oxides for } \\
\mathrm{Th}, \mathrm{Zr}, \mathrm{Pu} \text { and hydroxycarbonates for } \mathrm{Pb} \text {. The following is from (2) and } \\
\text { was conducted by adding } \mathrm{Th}(\mathrm{IV}) \text { to water equilibrated with concrete and } \\
\mathrm{pH} \text { adjusted: solubility ranged from } 1 \mathrm{e}-8 \mathrm{M} \text { to } 4 \mathrm{e}-9 \mathrm{M} \text { as } \mathrm{pH} \text { increased }\end{array}$ \\
\hline
\end{tabular}




\begin{tabular}{|c|c|c|c|c|c|c|c|}
\hline \multirow[t]{2}{*}{$\begin{array}{l}\text { Radio- } \\
\text { nuclide }\end{array}$} & \multicolumn{2}{|c|}{$\begin{array}{l}\text { Young Cement } \\
1^{\text {st }} \text { Stage } \\
(\mathrm{pH} \sim 12.5)\end{array}$} & \multicolumn{2}{|c|}{$\begin{array}{l}\text { Moderately-aged } \\
\text { Cement, } 2^{\text {nd }} \text { Stage } \\
\quad(\mathrm{pH} \sim 10.5)\end{array}$} & \multicolumn{2}{|c|}{$\begin{array}{l}\text { Aged Cement }^{(b)} \\
3^{\text {rd }} \text { Stage } \\
(\mathrm{pH} \sim 5.5)\end{array}$} & \multirow[b]{2}{*}{ Comments/References $^{(\text {(a) }}$} \\
\hline & $\begin{array}{c}\text { Conser- } \\
\text { vative }\end{array}$ & "Best" & $\begin{array}{c}\text { Conser- } \\
\text { vative }\end{array}$ & "Best" & $\begin{array}{c}\text { Conser- } \\
\text { vative }\end{array}$ & "Best" & \\
\hline $\mathrm{Th}, \mathrm{Zr}, \mathrm{Sn}$ & & & & & & & $\begin{array}{l}\text { from } 8.3 \text { to } 12.9 \text {. In essence, the solubility didn't change for Th. Sn } \\
\text { exists in the tetravalent state, }(\mathrm{Sn}(\mathrm{IV}) \text {, under the cementitious conditions } \\
\text { and readily hydrolyses in the } \mathrm{pH} \text { range }>8 \text {. It sorbed to the same extent } \\
\text { as Th(IV) to sulfate resistant Portland cement (2). Calculations of } \mathrm{Pb}, \mathrm{Pu} \\
\mathrm{Th} \text {, and } \mathrm{Zr} \text { solubility under cementitious conditions have been conducted } \\
(4,7) \text {. }\end{array}$ \\
\hline $\mathrm{U}(\mathrm{VI})$ & $5 \times 10^{-6}$ & $10^{-1}$ & $5 \times 10^{-6}$ & $10^{-1}$ & $5 \times 10^{-5}$ & $10^{-6}$ & $\begin{array}{l}\text { Solubility controlling phases are likely U(VI) hydrous oxide [schoepite] } \\
\text { and uranophase [calcium U(VI) silicate] }(4,7) \text {. Brady and Kozak (7) } \\
\text { calculated a solubility of le-8 M U(VI). }\end{array}$ \\
\hline \multicolumn{8}{|c|}{ 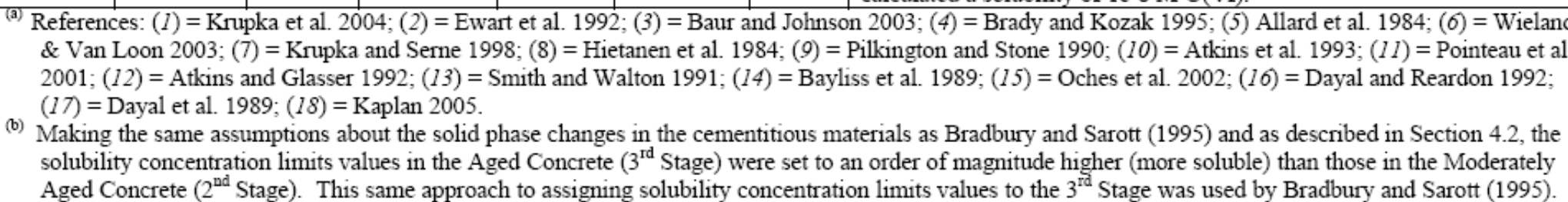 } \\
\hline
\end{tabular}




\subsection{ATTACHMENT G - CONTAMINANT SOLUBILITY DATA FOR CHEMICALLY RECUCING REFERENCE CASE CEMENTITIOUS MATERIALS}


Table G-1. Radionuclide solubility data for reduced young, moderately aged and aged concrete [9].

Table 12. Apparent solubility concentration limits ( $\mathrm{mol} / \mathrm{L}$ or $\mathrm{M}$ ) for Reducing Cementitious Solids

\begin{tabular}{|c|c|c|c|c|c|c|c|}
\hline \multirow[t]{2}{*}{$\begin{array}{l}\text { Radio- } \\
\text { nuclide }\end{array}$} & \multicolumn{2}{|c|}{$\begin{array}{l}\text { Young Cement } \\
1^{\text {st }} \text { Stage } \\
(\mathrm{pH} \sim 12.5)\end{array}$} & \multicolumn{2}{|c|}{$\begin{array}{c}\text { Moderately-aged } \\
\text { Cement, } 2^{\text {dd }} \text { Stage } \\
(\mathrm{pH} \sim 10.5)\end{array}$} & \multicolumn{2}{|c|}{$\begin{array}{l}\text { Aged Cement }^{(b)} \\
3^{\text {rd }} \text { Stage } \\
(\mathrm{pH} \sim 5.5) \\
\end{array}$} & \multirow[b]{2}{*}{ Comments/References $^{(a)}$} \\
\hline & $\begin{array}{l}\text { Conser } \\
\text {-vative }\end{array}$ & "Best" & $\begin{array}{c}\text { Conser- } \\
\text { vative }\end{array}$ & "Best" & $\begin{array}{c}\text { Conser- } \\
\text { vative }\end{array}$ & "Best & \\
\hline \multicolumn{2}{|c|}{$\begin{array}{l}{ }^{3} \mathrm{H}, \mathrm{Cl}, \mathrm{Kr}, \mathrm{Rn}, \mathrm{Sr} \\
\mathrm{Ra}, \mathrm{Zr}, \mathrm{Th}, \mathrm{Nb}, \mathrm{Sn} \\
\mathrm{I}, \mathrm{Cs}, \mathrm{Ac}, \mathrm{Am}, \mathrm{Cf} \\
\mathrm{Cm}, \mathrm{Eu}, \mathrm{Po}, \mathrm{Se}, \mathrm{C} \\
\mathrm{Co}, \mathrm{Ni}, \mathrm{Pb}, \mathrm{Bk}, \mathrm{Sm} \\
\mathrm{Fr}, \mathrm{Gd}, \mathrm{At}, \mathrm{Ar}, \mathrm{Te} \\
\quad \mathrm{Ba},\end{array}$} & \multicolumn{5}{|c|}{$\begin{array}{l}\text { These radionuclides are assumed to have the same } \\
\text { apparent solubility values as for the Oxidizing } \\
\text { Cementitious Solids (Table 11). }\end{array}$} & $\begin{array}{l}\text { The solubility of a number of other metals would likely be further lowered in } \\
\text { a concrete that contains blast furnace slag (BFS) because BFS greatly } \\
\left.\text { increases the concentration of sulfides ( } \mathrm{S}^{2}\right) \text { in the porewater }(l) \text {. Sulfide } \\
\text { concentrations in BFS concrete porewater have been measured as high as } \\
1100 \mathrm{mg} / \mathrm{L}(I) \text {. However, there hasn't been any experimental or theoretical } \\
\text { work to substantiate the assertion that metal sulfides form and lower the } \\
\text { solution concentrations of metals in this group below concentrations } \\
\text { presented in Table } 11 \text {. }\end{array}$ \\
\hline $\begin{array}{l}\text { Tc(IV), Re } \\
\text { (IV) }\end{array}$ & $10^{-9}$ & $10^{-10}$ & $10^{-9}$ & $10^{-10}$ & $10^{-9}$ & $10^{-10}$ & $\begin{array}{l}\text { Bayliss et al. (2) adsorbed Tc onto Portland cement or concrete in an anoxic } \\
\text { glove box with } 0.05 \mathrm{M} \text { dithionite in } 1.5 \mathrm{M} \mathrm{NaCl} \text { for } 28 \text { days in } 50: 1 \\
\text { water:crushed cement: } K d=5000 \mathrm{~mL} / \mathrm{g} \text { and measured Tc solution } \\
\text { concentration was } 1 \mathrm{e}-11 \mathrm{M} \text {. Assuming Tc2 } \mathrm{S}_{7} \text { as the solubility controlling } \\
\text { phase, MMES (1992; Appendix D) calculated that reducing grout used in the } \\
\text { SRS saltstone program would maintain Tc at a concentration of } 1.4 \mathrm{e}-20 \mathrm{M} \\
(2.4 \mathrm{e}-8 \mathrm{pCi} / \mathrm{L}) \text {. Allard (4) calculated that reducing concrete would maintain } \\
\text { Tc at a concentration }<1 \mathrm{e}-10 \mathrm{M} \text {. It is assumed that the SRS cementitious } \\
\text { materials containing blast furnace slag remain reducing throughout all three } \\
\text { stages. }\end{array}$ \\
\hline $\begin{array}{l}\mathrm{Np} \text { (IV), } \\
\mathrm{Pa} \text { (IV) }\end{array}$ & $5 \times 10^{-3}$ & $10^{-6}$ & $5 \times 10^{-3}$ & $10^{-6}$ & $5 \times 10^{-4}$ & $10^{-5}$ & $\begin{array}{l}\text { Under reducing conditions, both } \mathrm{Np} \text { and } \mathrm{Pa} \text { are reduced from }+5 \text { to }+4 \text {. In } \\
\text { the tetravalent form they would be expected to sorb very strongly or be } \\
\text { insolble. Assume that metal hydroxide is the controlling solid. The } \\
\text { empirical laboratory data generated by Ewart et al. }(1992) \text { is much lower } \\
\text { than thermodynamic predictions }(2,4,7) \text {. Berry et al. } 1988 \text { reported that } \mathrm{Pa} \\
\text { sorbed very strongly, but due to experimental problems (sorption to } \\
\text { glassware and filters) was unable to come up with reliable cement sorption } \\
\text { values. It is assumed that the cementitious materials remain reducing } \\
\text { throughout all three stages. }\end{array}$ \\
\hline $\mathrm{Pu}(\mathrm{III} / \mathrm{IV})$ & $5 \times 10^{-9}$ & $10^{-10}$ & $5 \times 10^{-9}$ & $10^{-10}$ & $5 \times 10^{-8}$ & $10^{-9}$ & $\begin{array}{l}\mathrm{Pu}(\mathrm{IV}) \text { solubility measured by adding } \mathrm{Pu}(\mathrm{IV}) \text { spike into concrete rinsate } \\
\text { under reducing conditions without solid phase and adjusting } \mathrm{pH} \text { : from } 9 \text { to } \\
11 \text { the solubility was } 1 \mathrm{e}-10 \text { to } 5 \mathrm{e}-11 \text {; essentially not changing }(8) \text {. Assumed } \\
\mathrm{Pu}(\mathrm{OH})_{4} \text { controlled solubility. Based on thermodynamic calculations, }\end{array}$ \\
\hline
\end{tabular}


Reference Cases for Use in the Cementitious Barriers Partnership Project

anv

\begin{tabular}{|c|c|c|c|c|c|c|c|}
\hline \multirow[t]{2}{*}{$\begin{array}{l}\text { Radio- } \\
\text { nuclide }\end{array}$} & \multicolumn{2}{|c|}{$\begin{array}{l}\text { Young Cement } \\
1^{\text {st }} \text { Stage } \\
(\text { pH } \sim 12.5)\end{array}$} & \multicolumn{2}{|c|}{$\begin{array}{l}\text { Moderately-aged } \\
\text { Cement, } 2^{\text {vd }} \text { Stage } \\
\quad(p H \sim 10.5)\end{array}$} & \multicolumn{2}{|c|}{$\begin{array}{l}\text { Aged Cement } \\
3^{\text {rd }} \text { Stage } \\
(\mathrm{pH} \sim \mathbf{5 . 5})\end{array}$} & \multirow[b]{2}{*}{ Comments/References $^{(a)}$} \\
\hline & $\begin{array}{l}\text { Conser } \\
\text {-vative }\end{array}$ & "Best" & $\begin{array}{c}\text { Conser- } \\
\text { vative }\end{array}$ & "Best" & $\begin{array}{c}\text { Conser- } \\
\text { vative }\end{array}$ & "Best & \\
\hline & & & & & & & $\begin{array}{l}\text { solubility limits under reducing cementitious conditions were estimated to be } \\
\text { less than } 10^{-9} \text { to } 10^{-10} \mathrm{M} \mathrm{Pu}(9) \text {. It is assumed that the cementitious materials } \\
\text { remain reducing throughout all three stages. }\end{array}$ \\
\hline $\mathrm{Pu}($ combo) & $5 \times 10^{-9}$ & $10^{-10}$ & $5 \times 10^{-9}$ & $10^{-10}$ & $5 \times 10^{-8}$ & $10^{-9}$ & $\begin{array}{l}\mathrm{Pu}(\text { combo) is a single geochemical parameter for } \mathrm{Pu} \text { taking into account its } \\
\text { many oxidation states. For this system, all } \mathrm{Pu} \text { is assumed to exist in the }+4 \\
\text { oxidation state. }\end{array}$ \\
\hline $\mathrm{U}$ & $5 \times 10^{-5}$ & $10^{-6}$ & $5 \times 10^{-6}$ & $10^{-7}$ & $5 \times 10^{-6}$ & $10^{-7}$ & $\begin{array}{l}\mathrm{U}(\mathrm{IV}) \text { solubility measured by adding U(IV) spike into concrete rinsate under } \\
\text { reducing conditions without solid phase and adjusting } \mathrm{pH} \text { : from } 5 \text { to } 13 \text { the } \\
\text { solubility was } 8 \mathrm{e}-7 \text { to } 2 \mathrm{e}-7 \text {; essentially not changing over that entire } \mathrm{pH} \\
\text { range }(8) \text {. This wide } \mathrm{pH} \text { range suggests that the solubility concentration } \\
\text { limits does not change as a function of cement Stage. Assumed } \mathrm{UO}_{2} \text { (crystal) } \\
\text { and } \mathrm{UO}_{2} \text { (amorph) were the solubility controlling phases. Based on } \\
\text { thermodynamic calculations, solubility limits of U under reducing } \\
\text { cementitious conditions were estimated to be less than } 10^{-9} \text { to } 10^{-10} \mathrm{M} \mathrm{U}(\mathrm{IV}) \\
\text { (9). It is assumed that the cementitious materials remain reducing throughout } \\
\text { all three stages. }\end{array}$ \\
\hline \multicolumn{8}{|c|}{$\begin{array}{l}\text { (a) References: }(1)=\text { Angus and Glasser } 1985 ;(2)=\text { Bayliss et al. 1991; }(3)=\text { MMES } 1992 ;(4)=\text { Allard } 1984 ;(5)=\text { Bajt et al. 1993; }(6)=\text { Macias et al. 1997; }(7) \\
=\text { Rai and Szelmeczka } 1990 ;(8)=\text { Ewart et al. } 1992 ;(9)=\text { Brady and Kozak } 1995 \text {. } \\
\text { (b) Discussion of the age of each of the stages is facility specific because it depends on the amount of water that passes through the cementitious material (see } \\
\text { Section 4.2.4). }\end{array}$} \\
\hline
\end{tabular}




\subsection{ATTACHMENT H - DISTRIBUTION COEFFICIENTS FOR SOIL}


Table H-1. Typical SRS Soil Physical Properties [4,11].

\begin{tabular}{|c|c|c|c|c|c|c|c|c|c|}
\hline \multirow[b]{2}{*}{ Material } & \multicolumn{3}{|c|}{$\begin{array}{c}\text { Saturated Hydraulic } \\
\text { Conductivity }\end{array}$} & \multicolumn{2}{|c|}{ Typical Water Content ${ }^{1}$} & \multicolumn{4}{|c|}{ Bulk Properties } \\
\hline & $\begin{array}{c}\mathrm{K}_{\mathrm{h}} \\
(\mathrm{cm} / \mathrm{s})\end{array}$ & $\begin{array}{c}\mathrm{K}_{\mathrm{v}} \\
(\mathrm{cm} / \mathrm{s})\end{array}$ & $\mathrm{k}_{\mathrm{h}} / \mathrm{k}_{\mathrm{v}}$ & Saturation & $\begin{array}{c}\text { Volumetric } \\
\text { Water } \\
\text { Content }\end{array}$ & $\begin{array}{c}\text { Saturated } \\
\text { Effective } \\
\text { Diffusion } \\
\text { Coefficient, } \\
\mathrm{D}_{\mathrm{e}}\left(\mathrm{cm}^{2} / \mathrm{s}\right) \\
\end{array}$ & $\begin{array}{c}\text { Total } \\
\text { Porosity } \\
(\%)\end{array}$ & $\begin{array}{c}\text { Dry } \\
\text { Bulk } \\
\text { Density } \\
\left(\mathrm{g} / \mathrm{cm}^{3}\right)\end{array}$ & $\begin{array}{l}\text { Particle } \\
\text { Density } \\
\left(\mathrm{g} / \mathrm{cm}^{3}\right)\end{array}$ \\
\hline $\begin{array}{l}\text { Sand } \\
(<25 \% \\
\text { Mud })\end{array}$ & $\begin{array}{c}5.0 \mathrm{E}- \\
04\end{array}$ & $\begin{array}{c}2.8 \mathrm{E}- \\
04\end{array}$ & 1.8 & $\begin{array}{c}0.665 \text { to } \\
0.708\end{array}$ & $\begin{array}{c}0.253 \text { to } \\
0.269\end{array}$ & 8.0E-06 & 38 & 1.65 & 2.66 \\
\hline $\begin{array}{l}\text { Clay- } \\
\text { Sand } \\
(25- \\
50 \% \\
\text { Mud }) \\
\end{array}$ & $\begin{array}{c}8.3 \mathrm{E}- \\
05\end{array}$ & $\begin{array}{c}2.1 \mathrm{E}- \\
05\end{array}$ & 4.0 & $\begin{array}{c}0.843 \text { to } \\
0.874\end{array}$ & $\begin{array}{c}0.312 \text { to } \\
0.323\end{array}$ & $5.3 \mathrm{E}-06$ & 37 & 1.68 & 2.67 \\
\hline $\begin{array}{l}\text { Clay } \\
(>50 \% \\
\text { Mud })\end{array}$ & $\begin{array}{c}2.0 \mathrm{E}- \\
06\end{array}$ & $\begin{array}{c}9.5 \mathrm{E}- \\
07\end{array}$ & 2.1 & $\begin{array}{c}0.920 \text { to } \\
0.934\end{array}$ & $\begin{array}{c}0.396 \text { to } \\
0.402\end{array}$ & $4.0 \mathrm{E}-06$ & 43 & 1.52 & 2.67 \\
\hline
\end{tabular}

1 The typical matrix potential (pore pressure) of vadose zone soils at SRS ranges from -125 to $-175 \mathrm{~cm}-\mathrm{H}_{2} 0$ (Nichols et al. 2000); the range of saturation and volumetric water content provided is based upon the characteristic curves produced by Phifer et al. 2006 and the typical range of vadose zone soil matrix potential from Nichols et al. 2000. 
Table H-2. Soil Kds

\begin{tabular}{|c|c|c|c|c|c|}
\hline \multirow{2}{*}{$\begin{array}{l}\text { Radio- } \\
\text { nuclide }\end{array}$} & \multicolumn{2}{|c|}{ Sandy Sediment } & \multicolumn{2}{|c|}{ Clayey Sediment } & \\
\hline & $\begin{array}{l}\text { Conser- } \\
\text { vative }\end{array}$ & "Best" & $\begin{array}{l}\text { Conser- } \\
\text { vative }\end{array}$ & "Best" & Comments/References $^{(a)}$ \\
\hline & & & & & $\begin{array}{l}\text { In this study, } \mathrm{Np} \mathrm{Kd} \text { values for a soil ( } \mathrm{pH}=5.1 \text {, cation exchange capacity }=2.5 \mathrm{meq} / 100 \mathrm{~g}, 3.6 \% \\
\text { silt, } 0.5 \% \text { clay, } \mathrm{CaCO} \mathrm{CO}_{3}=<0.2 \mathrm{mg} / \mathrm{kg} \text { ) were } 0.25 \text { and } 0.16 \mathrm{~mL} / \mathrm{g} \text {. This sediment is lower in clay } \\
\text { content and pH than our assumed typical sediments for the "Sandy Sediment" or "Clayey } \\
\text { Sediment". Therefore higher values were chosen herein. Np will exist primarily as NpO }{ }_{2}^{+}(21) \text {. It } \\
\text { has been shown that } \mathrm{Np} \text { : } 1 \text { ) sorbs moderately to iron oxides and clays, } 2 \text { ) does not compete } \\
\text { favorably with dissolved } \mathrm{Ca} \text { or other divalent ions, } 3 \text { ) sorption is strongly pH dependent, and } 4) \\
\text { does not readily convert to Np(IV) under ambient groundwater conditions }(21) \text {. Due to lack of } \\
\text { experimental data, extra conservatism is included in "Conservative" estimates. }\end{array}$ \\
\hline $\mathrm{Pu}(\mathrm{V} / \mathrm{VI})$ & 11 & 16 & 2500 & 5000 & 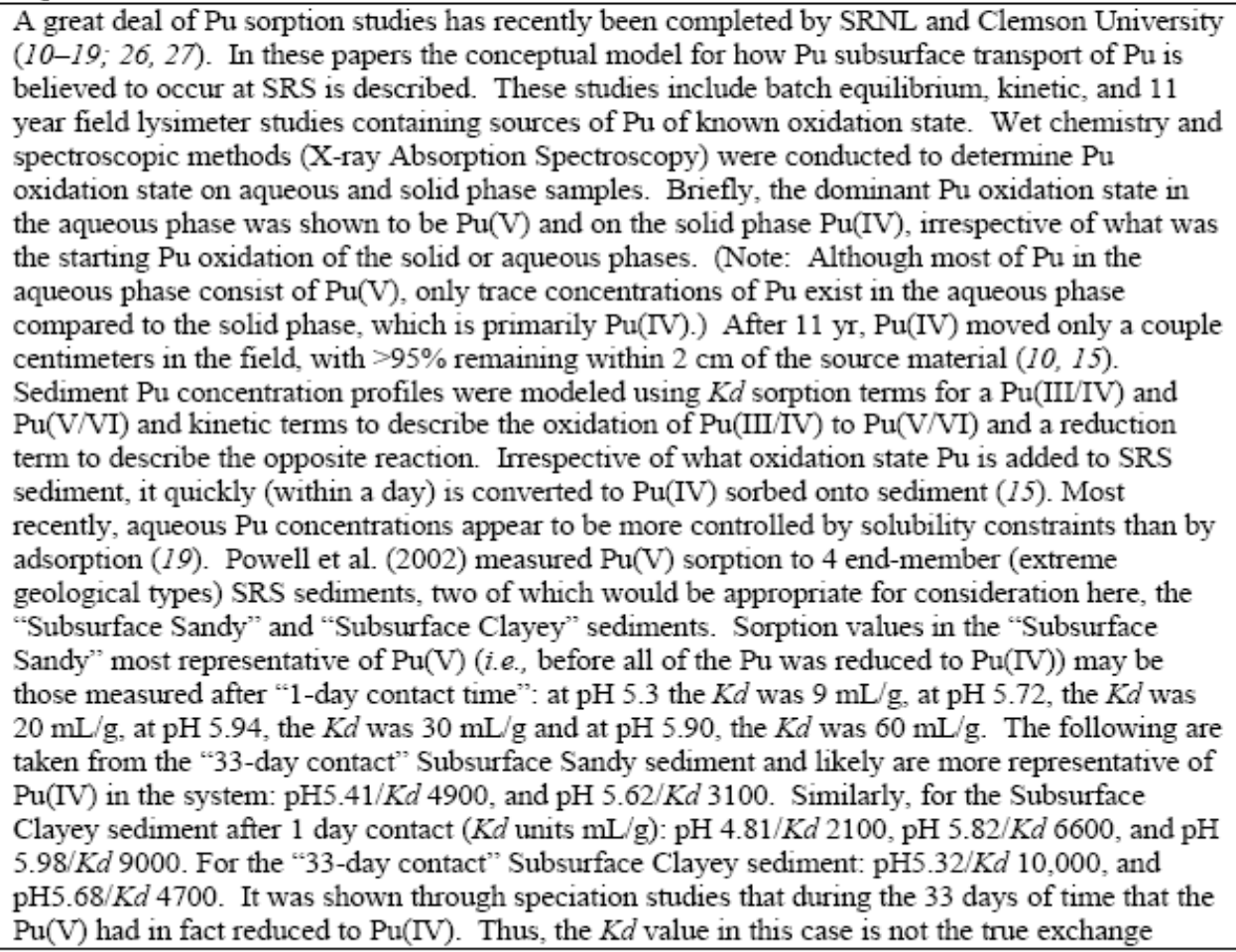 \\
\hline
\end{tabular}




\begin{tabular}{|c|c|c|c|c|c|}
\hline \multirow{2}{*}{$\begin{array}{l}\text { Radio- } \\
\text { nuclide }\end{array}$} & \multicolumn{2}{|c|}{ Sandy Sediment } & \multicolumn{2}{|c|}{ Clayey Sediment } & \multirow[b]{2}{*}{ Comments/References $^{(a)}$} \\
\hline & $\begin{array}{c}\text { Conser- } \\
\text { vative }\end{array}$ & "Best" & $\begin{array}{c}\text { Conser- } \\
\text { vative }\end{array}$ & "Best" & \\
\hline & & & & & $\begin{array}{l}\mathrm{Pu}(\mathrm{V}) \mathrm{K} d \text { value and it is clear that } \mathrm{Pu}(\mathrm{V}) \text { is unstable in the SRS subsurface. If the presence of both } \\
\mathrm{Pu}(\mathrm{IV}) \text { and } \mathrm{Pu}(\mathrm{V}) \text { are not included in the transport model, it is more accurate to assume that all the } \\
\mathrm{Pu} \text { exists as } \mathrm{Pu}(\mathrm{IV}) \text { since }>97 \% \text { of the Pu exists as } \mathrm{Pu}(\mathrm{IV}) \text { (19). Prout's (1958) frequently } \\
\text { referenced research with } \mathrm{Pu} \text { is purposely not applied here because of compromised experimental } \\
\text { procedures. Furthermore, emphasis of the selection of data was placed on the most recent data, } \\
\text { where controls of the Pu speciation were monitored and attempts were made to understand the } \\
\text { differences between the sorption behavior of the various Pu oxidation states. }\end{array}$ \\
\hline $\mathrm{Pu}(\mathrm{III} / \mathrm{IV})$ & 200 & 300 & 3000 & 6000 & $\begin{array}{l}\text { Powell et al. (2002) using a subsurface SRS sandy sediment and adding Pu(IV), reported a } K d \text { of } \\
220 \text { at } \mathrm{pH} 4.5 \text { and } 390 \mathrm{~mL} / \mathrm{g} \text { at } \mathrm{pH} 5.85 \text {. Using a SRS subsurface clay sediment and adding } \\
\mathrm{Pu}(\mathrm{IV}) \text {, they report } K d \text { values of } 2100 \mathrm{~mL} / \mathrm{g} \text { at } \mathrm{pH} 4.81,6600 \mathrm{~mL} / \mathrm{g} \text { at } \mathrm{pH} 5.82 \text {, and } 9000 \mathrm{~mL} / \mathrm{g} \text { at } \\
\mathrm{pH} 5.98 \text {. The "typical" sediment is assumed to have a pH of } 5.5 \text {. } \\
\text { (Also, see the Comments/References for } \mathrm{Pu}(\mathrm{V}) \text { in this table). }\end{array}$ \\
\hline $\mathrm{Pu}$ (combo) & 180 & 270 & 2950 & 5900 & $\begin{array}{l}\mathrm{Pu} \text { is a single geochemical parameter for } \mathrm{Pu} \text {. It is a hybrid value of } 90 \% \text { of the } \mathrm{Pu}(\mathrm{III} / \mathrm{IV}) \text { and } \\
10 \% \mathrm{Pu}(\mathrm{V} / \mathrm{VI}) \text { measured } \mathrm{Kd} \text { values. } \mathrm{Kaplan} \text { et al. (2004), in a laboratory experiment showed that } \\
\text { after } 50 \text {-hr that } 99 \% \text { of the } \mathrm{Pu} \text { added as } \mathrm{Pu}(\mathrm{V}) \text { had converted to } \mathrm{Pu}(\mathrm{IV}) \text { in the sediment/water } \\
\text { system. Demirkanli et at (2006) using computer simulation of a lysimeter study reported that } \\
\text { during a } 24 \mathrm{yr} \text { simulation that } 99.99 \% \text { of the Pu existed as } \mathrm{Pu}(\mathrm{III} / \mathrm{IV}) \text {. But reported that the the } \\
\text { short periods of time that } \mathrm{Pu} \text { existed in the oxidized form, it moved appreciably faster than } \mathrm{Pu} \text { in } \\
\text { the reduced form, } \mathrm{Pu}(\mathrm{IIIIV} / \mathrm{IV}) \text {, but clearly much slower than } \mathrm{Pu}(\mathrm{V} / \mathrm{VI}) \text {. }\end{array}$ \\
\hline Th, Zr & 75 & 900 & 100 & 2000 & $\begin{array}{l}\text { Tetravalent Cations: Kaplan and Serkiz (2004) reported that SRS sandy sediment had a } \mathrm{Zr}(\mathrm{IV}) \mathrm{Kd} \\
=991 \pm 352 \mathrm{~mL} / \mathrm{g} \text { at pH } 5.3 \text {; SRS clayey sediment had a } \mathrm{Zr}(\mathrm{IV}) \mathrm{K} d=1969 \pm 561 \mathrm{~mL} / \mathrm{g} \text { at pH } 5.3 \\
\text { (l). Kaplan and Serkiz (2004) reported that SRS sandy sediment had a Th(IV) } K d=245 \pm 0 \mathrm{~mL} / \mathrm{g} \\
\text { (the standard error is in fact zero) at pH 5.3; SRS clayey sediment Th(IV) } K d=99 \pm 48 \mathrm{~mL} / \mathrm{g} \text { at } \\
\text { pH } 5.3 \text { (I). The latter Th(IV) data appears suspect in that greater sorption to sand than clay is } \\
\text { inconsistent with basic principles of surface chemistry. This latter value will drive the uncertainty } \\
\text { high and the "Conservative" estimates low. Thibault et al. (1990) in their } K d \text { compilation of } \\
\text { sorption values from throughout the world provide a very wide range of Th } K d \text { values, with almost } \\
\text { all values being }>10,000 \mathrm{~mL} / \mathrm{g} \text {, however, a few values were as low as } 35 \mathrm{~mL} / \mathrm{g} \text {. }\end{array}$ \\
\hline $\begin{array}{c}\mathrm{Pb}, \mathrm{Po} \\
\mathrm{Sn}\end{array}$ & 500 & 2000 & 2500 & 5000 & $\begin{array}{l}\text { Divalent Soft Metals: Bibler and Marson (1992) reported that } \mathrm{Pb} K d \text { values for a SRS burial } \\
\text { ground sediment (TF } 1,40-60 \text { mesh) was generally }>10,000 \mathrm{~mL} / \mathrm{g} \text {, a second burial ground } \\
\text { sediment (TF2 } 40-60 \text { mesh) was } 63 \text { to } 925 \mathrm{~mL} / \mathrm{g} \text {, and a sediment from near the ETF ( } 40-60 \text { mesh) } \\
\text { facility had } \mathrm{Pb} \mathrm{Kd} \text { values generally }>2,000,000 \mathrm{~mL} / \mathrm{g} \text {. It appears quite likely that all these } \\
\text { experiments were conducted at concentrations above the solubility of } \mathrm{Pb} \text {, and thus reflect } \\
\text { precipitation more than adsorption; the experiments were conducted at an initial } \mathrm{Pb} \text { concentration } \\
\text { of } 5 \mathrm{mg} / \mathrm{L} \mathrm{Pb} \mathrm{Pb}^{2+} \text {. Furthermore, the }<40 \text {-mesh fraction of the sediment was not included in these } \\
\text { experiments, thus greater sorption would likely have been measured with the entire sediment. In a }\end{array}$ \\
\hline
\end{tabular}


Reference Cases for Use in the Cementitious Barriers Partnership Project

\begin{tabular}{|c|c|c|c|c|c|}
\hline \multirow{2}{*}{$\begin{array}{l}\text { Radio- } \\
\text { nuclide }\end{array}$} & \multicolumn{2}{|c|}{ Sandy Sediment } & \multicolumn{2}{|c|}{ Clayey Sediment } & \multirow[b]{2}{*}{ Comments/References $^{(a)}$} \\
\hline & $\begin{array}{c}\text { Conser- } \\
\text { vative }\end{array}$ & "Best" & $\begin{array}{c}\text { Conser- } \\
\text { vative }\end{array}$ & "Best" & \\
\hline & & & & & $\begin{array}{l}\text { compilation put together for groundwater modelers throughout the world, the estimated range of } \\
K d \text { values for sediments with a pH of } 4 \text { to } 6.3 \text { was } 940 \text { to } 8,650 \mathrm{~mL} / \mathrm{g} \text {. Finally, these elements tend } \\
\text { to have low solubility values. Solubility limits can easily be exceeded by these elements. } \\
\text { Therefore it is especially important to consider using solubility constraints rather than } K d \text { values } \\
\text { when concentrations are slightly elevated for these elements. }\end{array}$ \\
\hline $\begin{array}{c}\mathrm{Sr}, \mathrm{Ra} \\
\mathrm{Ba}\end{array}$ & 4 & 5 & 12 & 17 & $\begin{array}{l}\text { Alkaline Earth Elements (Group IIA): Kaplan and Serkiz (2004) reported that SRS sandy sediment } \\
\mathrm{Sr} K d=5 \pm 1 \mathrm{~mL} / \mathrm{g} \text { at } \mathrm{pH} 5.3 ; \mathrm{SRS} \text { clayey sediment } \mathrm{Sr} K d=17 \pm 0 \mathrm{~mL} / \mathrm{g} \text { at } \mathrm{pH} 5.3 \text {. Hoeffner } \\
(1985) \text { reported } \mathrm{SRS} \text { sandy sediment ( } 9 \% \text { clay) } \mathrm{Sr} K d=3 \mathrm{~mL} / \mathrm{g}, \mathrm{pH} \sim 4.7 ; \mathrm{SRS} \text { clayey sediment } \\
\text { (23\% clay) } \mathrm{Sr} K d=9 \mathrm{~mL} / \mathrm{g}, \mathrm{pH} \sim 4.7 ; \text { very strong pH effect on } \mathrm{Sr} K d \text { values on SRS sediments: for } \\
\text { sandy sediment ( } 9 \% \text { clay) between } \mathrm{pH} 2 \text { to } 4.8 \text { (background) } K d \text { slightly increased from } 4 \text { to } 19 \text {, } \\
\text { then increased sharply from } \mathrm{pH} 4.8 \text { to } 6.0-7.0 \text {, where the } K d \text { became } 2000 \mathrm{~mL} / \mathrm{g} \text {, then the } K d \\
\text { decreased gradually to } 100 \mathrm{~mL} / \mathrm{g} \text { as the } \mathrm{pH} \text { increased to } \mathrm{pH} 11 \text { (2). Prout's work (1958) with } \mathrm{Sr} \text { is } \\
\text { purposely not applied here because of compromised experimental procedures. Sr sorption is } \\
\text { almost entirely by cation exchange ( } 25 \text { ), and as such, is readily reversible upon changes in } \\
\text { groundwater chemistry. Estimates in look-up table reflect this weak-sorption mechanism. }\end{array}$ \\
\hline $\mathrm{Se}, \mathrm{Te}$ & 800 & 1000 & 800 & 1000 & $\begin{array}{l}\text { Selenate }\left(\mathrm{SeO}_{4}{ }^{2}\right) \text { ) sorbs strongly to } \mathrm{SRS} \text { sediments between the } \mathrm{pH} \text { values of } 3.9 \text { and } 6.7(24) \text {. } \\
\text { With } 0 \mathrm{mg} / \mathrm{L} \mathrm{C} \text { from fulvic acid added to SRS groundwater, selenate } \mathrm{Kd} \text { values for a clayey } \\
\text { subsurface SRS sediment were } 1041 \pm 0.7 \mathrm{~mL} / \mathrm{g} \text { at } \mathrm{pH} 3.9 ; 1041 \pm 0.4 \mathrm{~mL} / \mathrm{g} \text { at } \mathrm{pH} 5.3 \text {, and } 1041 \pm 0.3 \\
\mathrm{~mL} / \mathrm{g} \text { at } \mathrm{pH} 6.7(24) \text {. The authors remarked that there appeared to be an upper sorption limit } \\
\text { reached yielded such similar } K d \text { values as a function of } \mathrm{pH} \text {. Under similar experimental conditions } \\
\text { but using a subsurface sandy sediment, selenate } K d \text { values were } 1041 \pm 0 \mathrm{~mL} / \mathrm{g} \text { at } \mathrm{pH} 3.9,1311 \pm \\
384 \mathrm{~mL} / \mathrm{g} \text { at } \mathrm{pH} 5.3 \text {, and } 601 \pm 65 \mathrm{~mL} / \mathrm{g} \text { at } \mathrm{pH} 6.7(24) \text {. The sandy sediment, but not the clayey } \\
\text { sediment, showed the characteristic decrease in } K d \text { values as the } \mathrm{pH} \text { increased. Troubling, is that } \\
\text { the sandy sediment also had larger } K d \text { values than the clayey sediment. }\end{array}$ \\
\hline $\mathrm{Tc}, \operatorname{Re}$ & 0.05 & 0.1 & 0.1 & 0.2 & $\begin{array}{l}\mathrm{TcO}_{4}^{-} \text {exists in oxidized systems, including vadose zone. Hoeffner (1985) reported correlation } \\
\text { between clay content in SRS sediments and Tc } K d:<10 \% \text { clay } K d=0.17 \mathrm{~mL} / \mathrm{g}, \sim 10 \% \text { clay } K d= \\
0.14 \mathrm{~mL} / \mathrm{g}, \sim 10 \% \text { clay } K d=0.23 \mathrm{~mL} / \mathrm{g}, 11 \% \text { clay } K d=0.10 \mathrm{~mL} / \mathrm{g}, 30 \% \mathrm{clay} K d=0.33 \mathrm{~mL} / \mathrm{g}, 43 \% \\
\text { clay } K d=1.31 \mathrm{~mL} / \mathrm{g}, 45 \% \text { clay } K d=1.16 \mathrm{~mL} / \mathrm{g} \text {. Kaplan }(2005) \text { reported TcO }{ }_{4}^{-} \text {sorption to an SRS } \\
\text { sediment occurred only when the } \mathrm{pH} \text { was }<4.3 \text {; the } K d \text { values to this sandy subsurface sediment } \\
\text { increased from } 0 \text { at pH } 4.3 \text { to } \sim 0.11 \text { at pH } 3.7 \text {. Sorption studies with ReO }{ }_{4}^{-} \text {to a clayey subsurface } \\
\mathrm{SRS} \text { sediment in SRS groundwater as a function of pH all had a } K d \text { of } \sim 0 \mathrm{~mL} / \mathrm{g}:-0.6 \pm 0.6 \mathrm{~mL} / \mathrm{g} \text { at } \\
\mathrm{pH} 3.9 ;-0.3 \pm 0.1 \mathrm{~mL} / \mathrm{g} \text { at pH5.3; }-0.1 \pm 0.3 \mathrm{~mL} / \mathrm{g} \text { at pH } 6.7(24) \text {. Similar studies conducted with } \\
\text { sandy subsurface } \mathrm{SRS} \text { sediment also showed no sorption between the } \mathrm{pH} \text { of } 3.9 \text { and } 6.7: K d=-0.4 \\
\pm 0.3 \mathrm{~mL} / \mathrm{g} \text { at pH } 3.9, K d=-0.2 \pm 0.4 \mathrm{~mL} / \mathrm{g} \text { at pH5.3, and } K d=0 \pm 0.2 \mathrm{~mL} / \mathrm{g} \text { at } \mathrm{pH} 6.7(24) \text {. The } \\
\text { variability in these latter studies was quite high due to the limited number of replicates, two. } \\
\text { However, they indicate that Tc or Re sorption is either non-existent or very limited to SRS }\end{array}$ \\
\hline
\end{tabular}




\section{Reference Cases for Use in the Cementitious Barriers Partnership Project}

\begin{tabular}{|c|c|c|c|c|c|}
\hline \multirow{2}{*}{$\begin{array}{l}\text { Radio- } \\
\text { nuclide }\end{array}$} & \multicolumn{2}{|c|}{ Sandy Sediment } & \multicolumn{2}{|c|}{ Clayey Sediment } & \multirow[b]{2}{*}{ Comments/References $^{(a)}$} \\
\hline & $\begin{array}{c}\text { Conser- } \\
\text { vative }\end{array}$ & "Best" & $\begin{array}{c}\text { Conser- } \\
\text { vative }\end{array}$ & "Best" & \\
\hline & & & & & \begin{tabular}{|l} 
sediments. \\
sedimts
\end{tabular} \\
\hline $\mathrm{U}$ & 100 & 200 & 150 & 300 & 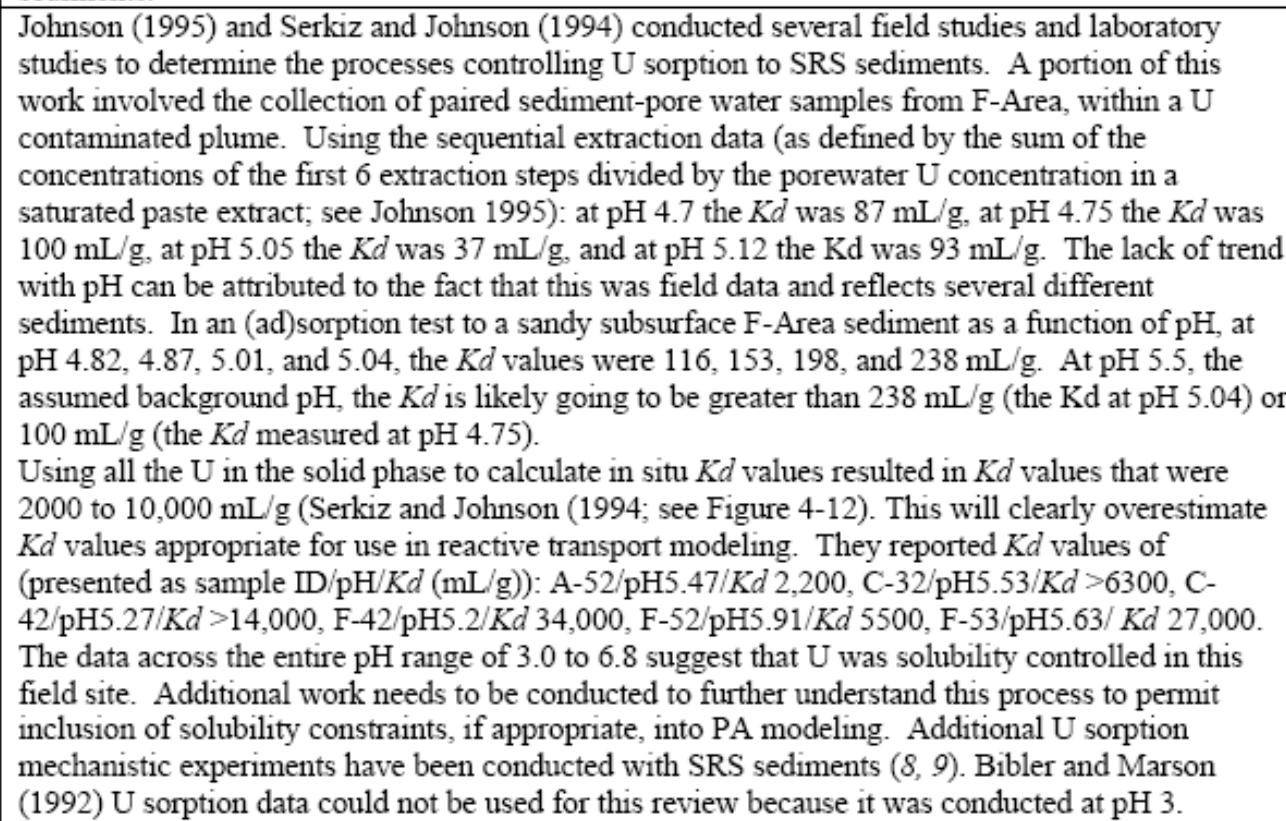 \\
\hline \multicolumn{6}{|c|}{ 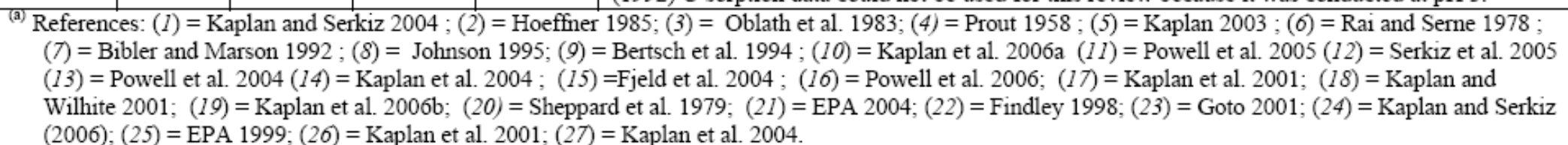 } \\
\hline
\end{tabular}




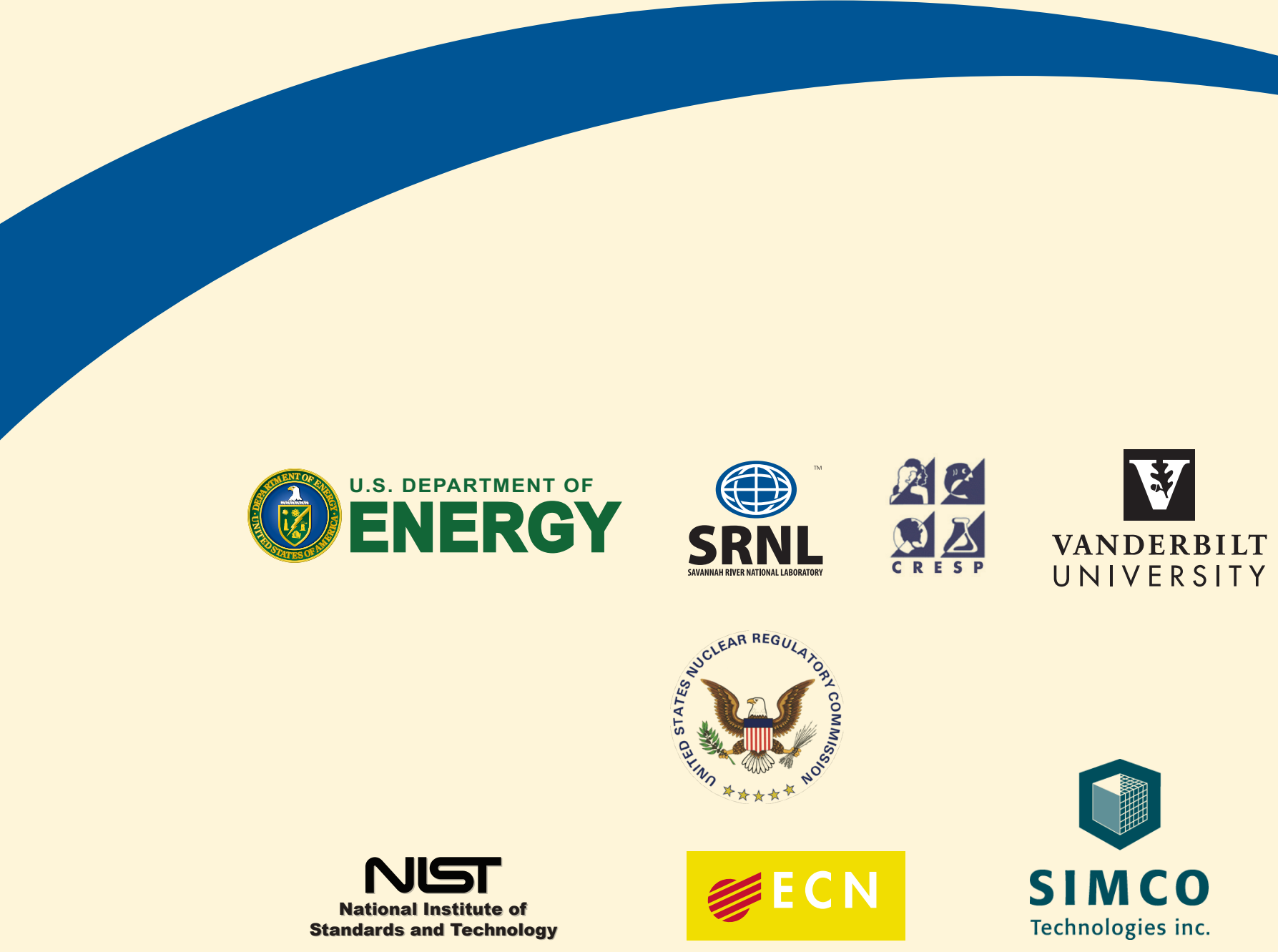

